Studia z etyki i antropologii filozoficznej „Filozofia Chrześcijańska” 18 (2021), s. 79-110

\author{
PIOTR DUCHLIŃSKI \\ Akademia Ignatianum w Krakowie \\ Instytut Filozofii \\ doi: $10.14746 /$ fc. 2021.18 .5
}

\title{
Filozofia chrześcijańska a obraz świata. Uwagi z perspektywy socjologii filozofii
}

\section{Perspektywa badawcza socjologii filozofii}

W artykule zamierzam podjąć problem mechanizmów akceptacji i instytucjonalnego utrwalania obrazu świata $\mathrm{w}$ filozofii chrześcijańskiej. Zostanie on przedstawiony na dość dużym poziomie ogólności, co może nie zadowolić krytyków oczekujących bardziej całościowego potraktowania sprawy. Użyte w tytule wyrażenia „filozofia chrześcijańska” i „obraz świata”, są wieloznaczne. Przypisywane im znaczenia, które możemy spotykać w rozmaitych opracowaniach, są konsekwencją różnych preferencji metafilozoficznych uwarunkowanych paradygmatycznie ${ }^{1}$. Nie zamierzam przywoływać różnych definicji filozofii chrześcijańskiej, które obecnie znajdują się w obiegu ani też wdawać się w polemiki dotyczące ich trafności². Sprawy historyczne również pozostawiam na boku. Aby jednak czytelnik miał jasność w kwestiach terminologicznych, postaram się sformułować projektujące charakterystyki filozofii

${ }^{1}$ Dobrze pokazuje ten pluralizm znaczeniowy różnych obrazów świata monografia Filozoficzne i naukowo-przyrodnicze elementy obrazu świata, red. A. Latawiec, A. Lemańska, Warszawa 1998.

${ }^{2}$ Zob. Z.J. Zdybicka, E.I. Zieliński, Chrześcijańska filozofia, w: Powszechna encyklopedia filozofii, red. A. Maryniarczyk i in., t. 2, Lublin 2001; K. Stachewicz, O filozofii chrześcijańskiej. Kilka uwag z perspektywy historycznej i futurologicznej, „Logos i Ethos” 2 (35), 2013, s. 219-234; S. Gałecki, O możliwości istnienia filozofii chrześcijańskiej, „Ruch Filozoficzny” 2016, nr 3, s. 117-132; P. Duchliński, A. Kobyliński, R. Moń, E. Podrez, Inspiracje chrześcijańskie w etyce, Kraków 2016. 
chrześcijańskiej i obrazu świata. Kolejna uwaga - uważam, że kluczowa dla niniejszych analiz - dotyczy perspektywy badawczej, w jakiej stawiam problem filozofii chrześcijańskiej i akceptowanego przez jej zwolenników obrazu świata. W tytule artykułu pojawia się wyrażenie „socjologia filozofii ${ }^{3 ”}$. Zachodzi konieczność objaśnienia, czym jest socjologia filozofii, gdyż u wielu czytelników, jak uważam, wyrażenie to może wywołać bardzo błędne skojarzenia prowadzące do posądzenia autora niniejszych analiz o jakąś formę redukcjonizmu socjologicznego, co byłby oczywiście sprzeczne z jego podstawowymi intencjami. Socjologia filozofii, jest w moim rozumieniu, działem socjologii wiedzy, czy też socjologii nauki, która w XX wieku przeżywała renesans na zachodzie Europy ${ }^{4}$. Socjologia filozofii to dyscyplina metanaukowa o charakterze empirycznym, aczkolwiek uwarunkowana określonymi presupozycjami filozoficznymi ${ }^{5}$. Jej głównym celem przedmiotowym jest odkrywanie struktur i mechanizmów funkcjonowania określonych zjawisk. Różnica między epistemologią a socjologią filozofii jest taka, że ta pierwsza opisuje i formułuje kryteria, a ta druga poszukuje mechanizmów; pierwsza jest normatywna, druga deskryptywna, choć ma tendencję do forsowania tez normatywnych. Wielu filozofów chrześcijańskich żywi mniej lub bardziej uzasadniony dystans wobec ustaleń różnych metanauk; począwszy od tak zwanych metanauk filozoficznych, jak filozofia nauki, metodologia ogólna, a skończywszy na ustaleniach metanauk humanistycznych i społecznych, jak właśnie wspomniana socjologia nauki. Niektóre wynikają z głęboko zakorzenionych (lękowych) uprzedzeń wobec pogłębionej refleksji metodologicznej bazującej na najnowszych ustaleniach nauk społecznych, dotyczących np. instytucjonalizacji czy dystrybucji wiedzy. Przywoływane obawy nie są dobrymi racjami za dystansem wobec

${ }^{3}$ „The term sociology of philosophy is relatively new: it is formed on analogy with the terms sociology of knowledge and sociology of science. In German, one speaks of Soziologie der Philosophie, in French, sociologie de la philosophie and in Spanish, sociología de la filosofía. In English, there is also the designation sociology of scientific knowledge, in which 'scientific' could be replaced with "philosophical'”. C.G. Heidegren, H. Lundberg, Towards a Sociology of Philosophy, „Acta Sociologica” 53 (2010), s. 4.

${ }^{4}$ Szerzej na temat socjologii wiedzy zob. H. Longino, The Social Dimensions of Scientific Knowledge, https://plato.stanford.edu/entries/scientific-knowledge-social/ [dostęp: 3.05.2021]; J. Niźnik, Socjologia wiedzy. Zarys historii i problematyki, Warszawa 1989; R. Sojak, Socjologia wiedzy chce pozostać nieświadoma. Uwagi o statusie poznawczym socjologii wiedzy, „Studia Socjologiczne" 1996, nr 4, s. 25-49; A. Szahaj, O tak zwanym mocnym programie socjologii wiedzy szkoty edynburskiej, „Kultura Współczesna” 1995, nr 1-2, s. 53-67; M. Ziółkowski, Wiedza. Jednostka. Spoteczeństwo, Warszawa 1989; Teoretyczne podstawy socjologii wiedzy, t. 1, red. P. Bytniewski, M. Chałubiński, Lublin 2006; K. Abriszewski, Budowanie sieci zamiast wiedzy. Krótkie wprowadzenie do ANT-ologii, w: Teoretyczne podstawy socjologii wiedzy, t. 1, red. P. Bytniewski, M. Chałubiński, Lublin 2006, s. 271- 287; R. Sojak, D. Wicenty, Zagubiona rzeczywistość. O społecznym konstruowaniu niewiedzy, Warszawa 2005.

${ }^{5}$ Zob. C.G. Heidegren, H. Lundberg, Towards a Sociology of Philosophy, s. 3-18. Autorzy szkicują program uprawiania nieredukcyjnej socjologii filozofii. 
rozstrzygnięć metanauk. Tak zakreślona perspektywa umożliwia potraktowanie filozofii chrześcijańskiej jako fenomenu empirycznego występującego w określonym typie kultury. Socjologa filozofii nie zaprzątają teoretyczne spory, które są utrapieniem dla filozofów, czy coś takiego jak filozofia chrześcijańska w ogóle istnieje. Dla socjologa filozofia chrześcijańska jest faktem; są bowiem badacze, którzy twierdzą, że realnie uprawiają coś takiego jak filozofia chrześcijańska, podejmują określone czynności badawcze, które prowadzą do zdeterminowanych rezultatów w postaci koncepcji, teorii, paradygmatów, ponadto składają bardzo wyraźne deklaracje metafilozoficzne, samych siebie nazywając wprost filozofami chrześcijańskimi ${ }^{6}$. Moje podejście do filozofii chrześcijańskiej nie ma charakteru angażującego, ale obserwacyjny. Interesuje mnie filozofia chrześcijańska jako zjawisko empiryczne, które powstało w kulturze europejskiej pod wpływem określonych przyczyn, których rekonstrukcją zajmuje się teoria tegoż zjawiska. Nie zamierzam jednak proponować całościowej koncepcji socjologii zjawiska filozofii chrześcijańskiej. Chcę jednie sformułować kilka uwag, które w przyszłości mogłyby zostać rozwinięte w ramach bardziej całościowego projektu. Uważam bowiem, że filozofię chrześcijańską można potraktować jako zjawisko empiryczne (fakt społeczny, fakt kulturowy o doniosłej roli kulturotwórczej) ${ }^{7}$ istniejące w świecie kultury; można obserwować i odkrywać mechanizmy jego powstawania i funkcjonowania w szerszej przestrzeni społecznej; można wreszcie ustalić, jakie czynniki skłaniają filozofa chrześcijańskiego do akceptacji takiego, a nie innego sposobu filozofowania ${ }^{8}$. Nie oznacza to, że trzeba być w tym celu zaangażowanym filozofem chrześcijańskim, który opowiada się za określonymi rozstrzygnięciami metodologicznymi i przedmiotowymi ${ }^{9}$. Takie podejście zwraca uwagę nie tylko na filozofię chrześcijańską jako kategorię teoretyczną, ale również na podmiot, czyli filozofa chrześcijańskiego, nosiciela określonego obrazu świata, który żyje i funkcjonuje w intersubiektywnej przestrzeni

${ }^{6}$ Sporo takich deklaracji można zaleźć w książce: Przewodnik po polskiej filozofii chrześcijańskiej XX i XXI wieku, red. P.S. Mazur, P. Duchliński, P. Skrzydlewski, Kraków 2020.

7 Potraktowanie filozofii jako zjawiska empirycznego generuje szereg pytań i problemów. „If we decide that the sociology of philosophy shall be a theory-based empirically practised sociological subdivision, questions of the following kind immediately present themselves: What kind of empirical material? Which empirical approach? What kind of data presentation? Which theory? Which key concepts? Which central problem areas? Which claims? Not all of these questions are addressed in the following presentation; the focus is on just some of them". C.G. Heidegren, H. Lundberg, Towards a Sociology of Philosophy, s. 4.

${ }^{8}$,The area studied by the sociology of philosophy is accordingly philosophical activity as a socially organized activity rooted in various historical and social contexts, an activity that includes the production of philosophical knowledge, that is to say, assertions and lines of reasoning that make claims to validity". Tamże, s. 4.

9 Zob. J. Pieter, Światopoglad humanisty, Katowice 2019, s. 100-102. Zwłaszcza rozdział dotyczący socjologii filozofii, tenże, O pochodzeniu filozofii, „Przegląd Filozoficzny” 1939, s. 1-64. 
kulturowej. Pisząc o obrazie świata, mam na myśli pewną wyidealizowaną kategorię (opisującą pewien typ idealny, nie do końca odpowiadający realnej rzeczywistości), która, jeśli bierzemy pod uwagę perspektywę socjologii filozofii, ma swoje umocowanie w umyśle indywidualnego podmiotu oraz we wspólnocie badawczej (grupie filozofów chrześcijańskich). Tyle wstępnych ustaleń na temat socjologii filozofii.

Sformułuję teraz kilka metanaukowych tez odnoszących się do kategorii „filozofia chrześcijańska”. W ramach niniejszych analiz o filozofii chrześcijańskiej będę mówił przede wszystkim jako o filozoficznej tradycji badawczej ${ }^{10}$. Jest ona kategorią metodologiczną, determinującą strukturę poznawczo-argumentacyjną, ale też historyczną, łączącą wymiar diachroniczny i synchroniczny. Filozofia jako tradycja badawcza jest zbiorem określonych idei, przekonań, które mniej lub bardziej komponują spójnie tzw. obraz świata. Kategoria „obraz świata” służy do treściowej charakterystyki filozofii chrześcijańskiej jako tradycji badawczej, która powstała w określonym czasie historycznym, przeszła w ciągu minionych wieków (i aktualnie też przechodzi) gruntowne przeobrażenia, współcześnie nadal jest podtrzymywana przez określone grupy badaczy (zaangażowanych konfesyjnie lub nie), którzy widzą w jej uprawianiu nie tylko określone wartości epistemiczne, ale też pozaepistemiczne, np. społeczne czy kulturowe. Dostrzegają, że za pomocą obrazu świata mogą wpływać na ludzkie działania tak w wymiarze indywidualnym, jak i społecznym. Obraz świata, a raczej, gwoli ścisłości, należałoby powiedzieć obrazy świata, które rozstrzygają o treściowej tożsamości filozofii chrześcijańskiej jako tradycji badawczej, pozostają dla socjologa filozofii w bezpośrednim związku ze wspólnotami badawczymi, wyrażającymi czy może lepiej powiedzieć - odzwierciedlającymi ich aktualnie przeżywane potrzeby (umysłowe i emocjonalne) oraz warunki życia społecznego. Oczywiście odczytanie stopnia tego odzwierciedlenia jest sprawą niełatwą, przeważnie zawsze zakłada określony stopień idealizacji.

Podsumowując, pragnę podkreślić, że na podstawie przeprowadzonej analizy nie zamierzam, co jest zgodne z metodologią nauk społecznych, w jakikolwiek sposób rozstrzygać o prawdziwości czy fałszywości określonych tez przedmiotowych głoszonych przez filozofów chrześcijańskich różnego

${ }^{10}$ Szerzej na temat filozofii chrześcijańskiej jako tradycji badawczej zob.: Przewodnik po polskiej filozofii chrześcijańskiej XX $i$ XXI wieku. Redaktorzy opracowania piszą we Wstępie: „Odwołując się do wypracowanej przez współczesnego filozofa nauki Larry’ego Laudana kategorii «tradycji badawczej», można powiedzieć, że filozofia chrześcijańska rozwijana w Polsce w ciągu ostatniego wieku stanowi właśnie taką tradycję. Składa się na nią wiele różnych sposobów uprawiania filozofii (neotomistyczny, fenomenologiczny, hermeneutyczny, dialogiczny czy analityczny) urzeczywistnianych w ramach różnych szkół filozoficznych lub też przez indywidualnych myślicieli, którzy zachowywali daleko idącą powściągliwość wobec przynależności do jakiekolwiek sformalizowanej szkoły filozoficznej”, s. 11. 
autoramentu. Proponowana socjologia filozofii nie jest uprawiana w ramach twardego programu tzw. socjologii wiedzy, który wypracowała szkoła edynburska $^{11}$. Nie twierdzę, że prawdziwość tez filozoficznych jest uwarunkowana sposobem ich odkrycia a następnie przyswojenia w trakcie ontogenezy poznania. Objaśnienie mechanizmu genezy akceptacji obrazów świata nie rozstrzyga o ich waloryzacji epistemologicznej. Uważam jednak, że ustalenia teoretyczne socjologów z Edynburga, pozbawione rzecz jasna radykalności pewnych sformułowań, mogą być przydatne do badania różnych koncepcji pojawiających się w naukach humanistycznych, a bez wątpienia taką nauką humanistyczną jest filozofia chrześcijańska ${ }^{12}$. Filozofia chrześcijańska rozumiana jako tradycja badawcza ma swoją własną wewnętrzną racjonalną logikę rozwoju, której rekonstrukcją zajmują się historycy filozofii. Chcąc ocenić racjonalność, spójność i konsekwencję argumentacyjnych posunięć filozofów chrześcijańskich, trzeba bezwzględnie odwołać się do tej wewnętrznej logiki. Przekonamy się jednak, że owa logika nie pozwala dogłębnie i jednoznacznie poznać tego, co faktycznie robią filozofowie chrześcijańscy, kiedy spojrzymy na ich profesję właśnie od strony genetycznej, od strony funkcjonowania pewnych mechanizmów społecznych i kulturowych. W teorii wszyscy chcą być racjonalistami. Upierają się, że ich profesja od A do $\mathrm{Z}$ jest zbiorem czynności racjonalnie skodyfikowanych. Nie dostrzegają jednak wpływu czynników społecznych, psychologicznych i kulturowych na kontekst akceptacji obrazu świata. Oczywiście, czynniki te nie mają charakteru nieracjonalnego, jak mogłoby się wydawać. Są to wytwory racjonalnych czynności ludzkich; wyrastają z określonych przekonań deskryptywnych i normatywnych ${ }^{13}$. Zwracając na nie uwagę, chcę podkreślić to, że filozofowie chrześcijańscy zasadniczo pomijają je w swoich argumentach, widząc w nich elementy relatywizujące obiektywną ważność argumentów. Dlatego też rola socjologii filozofii może być tutaj bardzo pomocna. Nie zastępuje ona merytorycznej refleksji epistemologicznej nad wewnętrzną logiką rozwoju filozofii chrześcijańskiej. Może jednak dostarczyć wartościowej poznawczo i merytorycznie wiedzy na temat czynionych przez filozofów tej tradycji założeń, które nie są przyjmowane jako konsekwencja racjonalnie skodyfikowanych argumentów. Niektórzy filozofowie chrześcijańscy chcą, aby ich argumenty zawsze przekonywały oponentów, aby działały na zasadzie niezawodnego algorytmu. Tymczasem argumenty filozoficzne

${ }^{11}$ Zob. J. Życiński, Racjonalność nauki a socjologiczny redukcjonizm Szkoły Edynburskiej, „Studia Philosophiae Christianae” 26 (1990), nr 1, s. 109-128.

12 „Inną wartościową formą modyfikacji Mocnego Programu mogłoby być ograniczenie jego stosowalności do tych dyscyplin humanistycznych, w których sugerowane mechanizmy społeczne mogą rzeczywiście odgrywać znaczącą rolę". Tamże, s. 126.

${ }_{13}$ Zob. J. Kmita, Z metodologicznych problemów interpretacji humanistycznej, Warszawa 1971; tenże, O kulturze symbolicznej, Warszawa 1982. 
formułowane są zawsze w tle szerszego kontekstu, który sam nie jest akceptowany na mocy stricte racjonalnych zasad, nie mówiąc o tym, że nie ma w tejże akceptacji nic z algorytmizacji. Jak zaznaczyłem, interesują mnie mechanizmy przyswajania i funkcjonowania określonych obrazów świata w tradycji filozofii chrześcijańskiej. Podkreślam, że odkrycie tych mechanizmów jest ważne dla lepszego zrozumienia roli obrazów świata w oswajaniu rzeczywistości ${ }^{14}$, a tym samym dla wykazania, że uprawianie filozofii chrześcijańskiej nie jest od A do $\mathrm{Z}$ racjonalnie zdeterminowanym zbiorem aktywności, ale zakłada osobiste, oparte na wierze epistemicznej, zaangażowanie (commitment) podmiotu $\mathrm{w}$ akceptowane na mocy indywidualnej decyzji założenia/przedzałożenia ${ }^{15}$. Nie chodzi tu zatem o zawierzenie religijne pewnym treściom objawionym (one też mają swoje miejsce w strukturze obrazu świata), ale o zawierzenie treściom uzyskanym w poznaniu naturalnym, czemu coś klasycznie nazywano preambula fidei. Zwartość treściowa obrazów (obrazu) nie będzie przedmiotem szczegółowej analizy, poza ogólnymi wzmiankami odnoszącymi się do ich struktury, problem ten pozostawiam na boku.

\section{Proponowane rozumienie obrazu świata}

Przejdźmy zatem do bliższego scharakteryzowania kategorii obraz świata. Być może trywialne wyda się czytelnikowi stwierdzenie, że zwolennicy każdej filozoficznej tradycji badawczej, w tym chrześcijańskiej, zakładają jakiś obraz świata. Powyżej stwierdziłem, że w ramach filozofii chrześcijańskiej rozumianej jako tradycja badawcza funkcjonują określone wyobrażenia, idee, przekonania; bliżej można by je charakteryzować za pomocą kategorii założenia/ /przedzałożenia i wskazać, że chodzi tu konkretnie o założenia metafizyczne, metodologiczne, epistemologiczne czy aksjologiczne. Uważam bowiem, że właśnie te założenia to nic innego jak pewien akceptowany obraz świata rozstrzygający o treściowej tożsamości danej tradycji. W literaturze przedmiotu zwraca się uwagę, że trzeba raczej mówić o różnych obrazach świata, a nie o obrazie świata ${ }^{16}$. Teza ta jest w pełni zasadna. A jeśli tak, to wstępnie możemy dokonać rozróżnienia na: potoczne, filozoficzne i naukowe obrazy świata. Wyróżnione obrazy pozostają względem siebie w różnych zależnoś$\operatorname{ciach}^{17}$. Najbardziej podstawowy, jeśli chodzi o zrozumienie i oswojenie rze-

${ }^{14}$ Umiarkowane podejście do programu socjologii wiedzy proponuje filozof nauki M. Hesse. Zob. M. Hesse, Revolutions and Reconstructions in the Philosophy of Science, Brington 1980.

${ }^{15}$ Wyrażeń „założenia” i ,przedzałożenia” używam zamiennie.

${ }^{16}$ Zob. Filozoficzne i naukowo-przyrodnicze elementy obrazu świata.

${ }_{17}$ Zob. W. Sellars, Philosophy and the Scientific Image of Man, w: tenże, Science, Perception and Reality, Atascadero [USA, California] 1991; T. Szubka, Wilfrid Sellars and the Two Images of 
czywistości, jest tzw. potoczny obraz świata. Jego przyswojenie jest, z ontogenetycznego punktu widzenia, pierwotne względem akceptacji innych obrazów, nie wymaga zbyt dużego zorganizowanego wysiłku poznawczego ani odbycia zaawansowanych studiów specjalistycznych. Każdy bowiem człowiek żyje w określonej kulturze, która jest nośnikiem potocznego obrazu świata. Obraz ten odzwierciedla podstawowe prawdy dotyczące struktury i funkcjonowania świata przyrodniczego i społecznego wyznawane przez członków tej kultury. Günter Abel, filozof nauki i hermeneuta, twierdzi, że faktem oczywistym jest to, iż ludzie żyją w różnych obrazach świata. Obrazy te mają charakter uniwersalny. Podzielane są z innymi ludźmi, mają zatem charakter wspólnotowy i intersubiektywny; stanowią fundament myślenia, języka i działania, rozstrzygają o prawdzie i fałszu stanu rzeczy. Abel podkreśla, że ludzie żyją „w obrazach świata", a nie obok nich, są w nich kognitywnie i egzystencjalnie zanurzeni bez możliwości ich epistemicznego przekroczenia ${ }^{18}$.

$\mathrm{Na}$ istotną rolę obrazów świata w heurezie teorii naukowych i filozoficznych zwraca uwagę polski kosmolog ks. Michał Heller. Uważa on, że obraz świata jest pewnym tłem wytworzonym przez określone czynniki kulturowe, społeczne i historyczne. Nauka i filozofia nie nasuwają jednoznacznie żadnego obrazu świata. Jest on konsekwencją określonej interpretacji, która dokonywana jest przez indywidualnego uczonego lub też przez wspólnotę badaczy pracujących $\mathrm{w}$ ramach wspólnie podzielanego paradygmatu teoretycznego. Obraz świata jest rezultatem naszego poznania; czy to potocznego, naukowego czy filozoficznego. Jest wynikiem czynności konceptualizacji dokonującej się przy użyciu aparatury pojęciowej i kategorii językowych, które przyswajamy $\mathrm{w}$ trakcie ontogenezy kultury, następnie poszerzamy w trakcie edukacji szkolnej. W skład każdego obrazu świata wchodzą przekonania: potoczne (zdroworozsądkowe), filozoficzne, naukowe i religijne. Stanowią one tworzywo, z którego mniej lub bardziej spójnie utkany jest obraz świata ${ }^{19}$. Proporcje między wyróżnionymi przekonaniami mogą układać się bardzo różnie.

the World, „Ruch Filozoficzny” LXXV (2019), nr 2, s. 131-144; D. Dennett, Dźwignie wyobraźni $i$ inne narzędzia do myślenia, tłum $Ł$. Kurek, Kraków 2015.

${ }^{18}$ Zob. G. Abel, Świat jako znak i interpretacja, thum. W. Małecki, Warszawa 2014. „[...] obraz ten jest tu rozumiany przede wszystkim jako podzielane z innymi ludźmi, przez ich przekazywanie i przejmowanie, kulturowo rozwijane tło w różnym stopniu teoretycznych sposobów ujmowania czynów; na podłożu tego tła i ze względu na nie konkretne działania następują tak jak następują”. Tamże, s. 97.

${ }^{19}$ Zob. M. Heller, Naukowy obraz świata a zadanie teologa, w: Obrazy świata $w$ teologii i naukach przyrodniczych, red. M. Heller, S. Budzik, S. Wszołek, Tarnów 1996, s. 13-28; M. Heller, Teologia $i$ wszechświat, Tarnów 2008; tenże, Nauka i Teologia - niekoniecznie tylko na jednej planecie, Kraków 2019; tenże, Naturalizm teologiczny Józefa Życińskiego, w: J. Życiński, Transcendencja i naturalizm, Kraków 2014. 
Precyzując: przez obraz(y) świata funkcjonujący(e) w filozofii chrześcijańskiej pojmowanej jako tradycja badawcza będę projektująco rozumiał pewien zbiór założeń lub przedłożeń (najczęściej ontologicznych, epistemologicznych i aksjologicznych), które akceptuje dany filozof, po pierwsze, po to, aby zrozumieć i oswoić świat, po drugie, aby w ogóle móc przeprowadzać jakikolwiek dyskurs argumentacyjny ${ }^{20}$. Obraz świata i wchodzące w jego skład założenia stanowią tzw. wiedzę tła, która determinuje argumentacyjne sposoby rozstrzygania formułowanych problemów teoretycznych i praktycznych. Zgodnie z proponowaną definicją teorie filozoficzne dostarczają treściowo heterogenicznych obrazów świata, co uwarunkowane jest historią, kulturą, wpływem nauki oraz osobistymi potrzebami, preferencjami. Heterogeniczność taka jest obecna również w obrębie filozofii chrześcijańskiej. Przykładów jej mamy aż nadto. Wszak inny obraz świata akceptują np. filozofowie tomistyczni, inny fenomenologowie, a jeszcze inny zwolennicy filozofii procesu czy dialogicy. W ramach jednej tradycji badawczej może być rozwijanych swobodnie wiele równolegle odmiennych obrazów świata, pozostających wobec sobie w stosunku wykluczania lub dopełniania. Obrazy te przeważnie nie są treściowo równoważne. Stąd też te same fakty empiryczne mogą uzyskiwać odmienne, nierównoważne interpretacje ${ }^{21}$. Jako przykład można podać różne wykluczające się interpretacje fenomenu zła i cierpienia. W związku z tym pojawia się problem: Za pomocą jakich kryteriów epistemologicznych można rozstrzygać o poprawności (pytanie, czy prawdziwości?) danej interpretacji? ${ }^{22} \mathrm{Na}$ obrazy świata składają się przekonania, konstytuu-

${ }^{20}$ Zob. J. Życiński, Teizm i filozofia analityczna, t. I, Kraków 1985.

${ }^{21} \mathrm{Na}$ problem empirycznego testowania równoważnych teorii zwraca uwagę Życiński, pisze tak: ,[...] status teizmu i ateizmu jest dokładnie jednakowy, kiedy rozważa się możliwość testowania empirycznego. Należy bowiem zauważyć, że zbiór potencjalnych falsyfikatorów tezy A (np. Bóg istnieje) jest równocześnie zbiorem konfirmującym negację tez tezy $\sim($,Nie jest prawdą, że Bóg istnieje”). Symetrycznie zbiór możliwych stanów niezgodnych z interpretacją ateistyczną $-\sim(\sim \mathrm{A})$ będzie stanowił konfirmację interpretacji teistycznych (A). Trudności z empirycznym testowaniem teizmu nie dostarczają więc argumentu za ateizmem, lecz co najwyżej mogłoby stanowić argument psychologiczny za agnostycyzmem. Status epistemologiczny podatności interpretacji teistycznej na testowanie negatywne jest taki sam jak status interpretacji ateistycznych. $Z$ twierdzenia tego nie wynika jednak, by wszelkie próby negatywnego testowania tych konkurencyjnych interpretacji były z góry skazane na niepowodzenie. Wynika jedynie, że w sposób aprioryczny nie można żadnej z nich przypisywać większej zgodności z empirystyczną teorią nauki. Przedstawione uwagi dotyczą możliwości testowania. Odrębnym zagadnieniem pozostaje natomiast kwestia teoretycznych możliwości uzasadnienia kryteriów stosowanych przy ocenie poszczególnych testów empirycznych oraz zasad ich rozstrzygającego charakteru. Pozytywne testy empiryczne, nawet wzajemnie sprzeczne, mogą bowiem być uważane za potwierdzenie różnorodnych, nawet wzajemnie sprzecznych interpretacji, jeśli tylko $\mathrm{z}$ interpretacji tych dają się wyprowadzić odnośne zdania obserwacyjne". Tamże, s. 84.

${ }^{22}$ Zob. J. Turek, Problem wyboru najlepszego wyjaśniania filozoficznego faktów naukowych, „Studia Philosophiae Christianae” 43 (2009), nr 1, s. 179-199; Z. Hajduk, Wartości epistemiczne: 
jące tzw. twarde jądro tradycji, z których łatwo nie można zrezygnować, oraz przekonania, z których na różnych etapach rozwijania tradycji, czy też konfrontacji jej z innymi tradycjami, można zrezygnować, nie naruszając jej tożsamości. Filozoficzne obrazy świata mają charakter całościowy, unifikujący, ich twórcy zmierzają do uzyskania synoptycznego widzenia rzeczywistości ${ }^{23}$. Do podstawowego korpusu twierdzeń należą tezy metafizyczne/ontologiczne, które - jak twierdzi wpływowy analityczny filozof Hilary Putnam - opisują podstawowe umeblowanie świata ${ }^{24}$. Obraz świata bowiem rozstrzyga o tym, co istnieje, a co nie istnieje, co jest wartościowe, a co nie jest wartościowe. Michał Heller zwraca uwagę, że „samo wyliczenie tych elementów uświadamia, że obraz świata jest tworem nieostrym, nieokreślonym o rozmytych brzegach. W niczym to nie przeszkadza jego niezwykłej skuteczności w kreowaniu gustów, kryteriów wartościowania i intelektualnych preferencji epoki”25. Tenże obraz świata - argumentuje Heller - ,jest obecny nie tylko w wypowiedziach, które dotyczą go wprost, lecz w podtekstach wielu wypowiedzi, które dotyczą całkiem czegoś innego; więcej - jest on obecny w całym klimacie kulturowym"26. W sposób szczególny zależność filozofii chrześcijańskiej od jakiegoś obrazu świata widoczna jest w warstwie językowej. Można by aforystycznie powiedzieć, pokaż mi, jaki masz język, a powiem ci, jaki masz obraz świata. Filozofowie chrześcijańscy nie zawsze zdają sobie sprawę z podskórnego oddziaływania tego obrazu. Wpływ ten ujawnia się najbardziej właśnie w doborze kategorii językowych, które wykorzystuje się do opisu świata i formułowania sposobów rozumowania zgodnych z przedkładanymi tezami.

Podsumujmy ten etap badań: filozof chrześcijański, będąc zawsze dzieckiem określonego czasu historycznego, żyje w jakimś obrazie świata, który podskórnie wpływa na jego sposób myślenia, postrzegania, tworzenia koncepcji, w których mowa o Bogu, człowieku i świecie. Sytuacja, w której filozof twierdziłby, że żyje poza jakimkolwiek obrazem światem, jest oczywiście epistemicznie do pomyślenia, ale praktycznie nie do zrealizowania. Dlatego ważne jest poznanie, w jaki sposób ów obraz przyswaja, czyniąc go swoim własnym obrazem świata. Na ten problem snop światła może rzucić socjologia filozofii.

aktualne kontrowersje w aksjologii nauki, w: Wartości dla życia, red. K. Popielski, Lublin 2008, s. 117-133; Z. Hajduk, Restrykcjonizm-ekspansjonizm: Spór o wartości poznawcze i pozapoznawcze w nauce, „Sprawozdania Towarzystwa Naukowego KUL” 34 (2005), nr 54, s. 55-73; tenże, Wartościowanie $i$ wartości w nauce, „Studia Philosophiae Chrstianae” 40 (2004), nr 2, s. 13-38.

${ }^{23}$ Zob. L. Nowak, Byt i myśl. U podstaw negatywistycznej metafizyki unitarnej, t. 1: Nicość i istnienie, Poznań 1998.

${ }^{24}$ Zob. H. Putnam, Wiele twarzy realizmu i inne eseje, thum. A. Grobler, Warszawa 1998.

${ }_{25}$ M. Heller, Naukowy obraz świata a zadanie teologa, s. 14.

${ }^{26}$ Tamże, s. 25. 


\section{Społeczne i podmiotowe mechanizmy akceptacji obrazu świata}

W akceptacji każdego obrazu świata biorą udział czynniki podmiotowe ${ }^{27}$. Dochodzi tutaj do głosu rola indywidualnego podmiotu oraz kontekstu kulturowego i społecznego, w jakim funkcjonuje. Działające w ramach tego kontekstu mechanizmy pozwalają uchwycić pewne prawidłowości, które w ostateczności doprowadzają do akceptacji chrześcijańskiego obrazu świata. Przede wszystkim obraz świata jest zawsze czymś, co jest przez podmiot przyswajane na drodze edukacji, która może przybrać mniej lub bardziej zinstytucjonalizowaną formę. Podmiot zawsze rodzi się w kulturze, w której istnieją mniej lub bardziej intersubiektywnie dostępne obrazy świata. Zastaje on pewne dominujące obrazy, których internalizacja gwarantuje mu oswojenie świata i normalne (przewidywalne) funkcjonowanie w grupie społecznej. Obrazy świata funkcjonujące w obrębie tradycji filozofii chrześcijańskiej są wysoce abstrakcyjne i spekulatywne, a ich przyjęcie związane jest $\mathrm{z}$ określonym treningiem kognitywno-praktycznym. Kultura i tradycja mogą stwarzać podatny grunt do przyswajania i akceptacji tego typu wyrafinowanych obrazów spekulatywnych. Polski psycholog Józef Pieter, który badał te problemy na gruncie socjologii filozofii, wskazywał, że określone

idee osobiste powstają i utrwalają się $\mathrm{w}$ wieku młodym [...]. Wpływ środowiska ujawnia się w sformułowaniu zagadnień, w układaniu ich w hierarchii według stopnia ważności, a może najbardziej w przychylaniu się do pewnych tylko rozwiązań ontologicznych i aksjologicznych powziętych lub przyjętych zarysowo, mgliście czy intuicyjne jeszcze przed zapoznaniem się z terminologią filozoficzną ${ }^{28}$.

Badania socjologiczne pokazują, że urabianie do akceptacji określonego obrazu świata, w tym do akceptacji tzw. chrześcijańskiego obrazu świata, rozpoczyna się najczęściej $\mathrm{w}$ określonym środowisku wychowawczym, może nim być np. rodzina lub jej najbliższe otoczenie, w którego obiegu funkcjonują idee i przekonania należące do religii chrześcijańskiej. Pieter pokazuje, że to właśnie

bezpośrednie środowisko wychowawcze, przede wszystkim dom rodzinny, związane jest licznymi więzami ze środowiskiem dalszym, strukturalnie podobnymi przekonaniami, w szczególności uprzedzenia światopoglądowe przyszłego filozofa [chrześcijańskiego - dod. P.D.], stają się do pewnych granic produktem

${ }_{27}$ Zob. J. Życiński, Struktura rewolucji metanaukowej. Studium rozwoju wspótczesnej nauki, Kraków 2013.

${ }^{28}$ J. Pieter, Światopogląd humanisty, s. 112; tenże, Problemy humanisty, Warszawa 2018. 
niepisanego poglądu na świat warstwy społecznej, towarzyskiej, kulturowej, z której pochodzi, i która go pośrednio i bezpośrednio wychowała ${ }^{29}$.

Każdy potencjalny filozof jest dzieckiem swojego czasu, wzrasta bowiem w określonym kontekście społecznym, który wywiera przemożny wpływ na jego myślenie i późniejsze wybory. Początkowo wpływ ten nie jest uświadamiany, rola wolności w akceptacji idei, wyobrażeń i przekonań o różnym statusie epistemicznym jest mocno ograniczona. Początkowa akceptacja treści funkcjonującego w kulturze obrazu świata pozbawiona jest jakichkolwiek wątpliwości.

Przyszły filozof [chrześcijański - dod. P.D.], styka się od pierwszych lat swojego życia ze swoistymi podnietami umysłowymi. Swoiste są jego rozmowy z rodzicami i bezpośrednimi wychowawcami, swoisty jest jego dostęp do pewnej, właściwej danemu domowi i szerszemu środowisku, literatury pięknej, naukowej i filozoficznej. Nacisk raz $\mathrm{w}$ raz powtarzany i zaledwie zauważany wywierają normy moralne i kodeks towarzyski, właściwy temu środowisku ${ }^{30}$.

Nie znaczy to, że jesteśmy niewolnikami tradycji kulturowej, w której przyszliśmy na świat. Do tego wątku jeszcze wrócę w tych analizach, tymczasem chciałbym podkreślić, że $\mathrm{z}$ epistemologicznego punktu widzenia racjonalna logika argumentacji nie jest ostatecznie rozstrzygająca dla akceptacji określonego obrazu świata, zwłaszcza na tym etapie rozwoju kognitywnego, o którym pisał cytowany Pieter. Proces wychowawczy nie polega tylko na racjonalnym perswadowaniu adeptowi danego obrazu świata, nie wyczerpuje się w agitowaniu czystymi argumentami.

Warto zwrócić uwagę także na inne czynniki, które mogą mieć znaczący wpływ na ową akceptację. Chodzi tu zwłaszcza o element swoistego osobistego zawierzenia, zaangażowania (commitment), który nie tylko występuje na etapie socjalizacji kulturowej, ale stale towarzyszy nam w akceptowaniu różnych treści poznawczych, docierających do nas na różnych etapach poznawczego rozwoju i edukacji. Element osobistego commitment jest epistemicznie nieusuwalną składową naszego poznania. Bez niej trudno byłoby nam zrozumieć, dlaczego ludzie są w stanie uwierzyć w najbardziej absurdalne obrazy świata, za którymi nie stoją żadne dobre racje. Zanim zaakceptujemy określone argumenty, zanim uznamy, że prawdziwa jest ta, a nie inna, koncepcja filozoficzna, zanim uznamy, że jakieś fakty naukowe są rozstrzygające dla danego problemu, najpierw musimy przyjąć na mocy aktu wiary epistemicznej

\footnotetext{
29 Tamże.

${ }^{30}$ Tamże, s. 112.
} 
jakiś obraz świata ${ }^{31}$. Na jego bazie mogą dopiero rozwijać się określone filozoficzne tradycje badawcze. W te obrazy świata - co raz jeszcze podkreślam po prostu wierzymy.

Z punktu widzenia realizmu ludzkiego poznania opisana sytuacja jest całkowicie normalna. Obrazy świata są podstawą dla teorii i praktyki ${ }^{32}$. To one rozstrzygają o tym, co jest prawdziwe, a co fałszywe, co jest dobre, a co złe. Obrazy te internalizujemy ${ }^{33}$, początkowo bezkrytycznie pod wpływem bezpośredniego środowiska wychowawczego, a dopiero w konsekwencji dalszego rozwoju i gromadzenia wiedzy, zwłaszcza poprzez edukację szkolną i uniwersytecką, zaczynamy w nie powątpiewać, co prowadzi do ich częściowej lub całościowej rewizji, nierzadko przypominającej remont statku płynącego po wzburzonych morskich falach. Początkowo musimy je zaakceptować właśnie na wiarę, aby następie $\mathrm{w}$ toku reorganizacji starej wiedzy albo częściowo je przebudować, albo też w całości odrzucić i zastąpić nowymi, bardziej adekwatnymi do naszych indywidualnych potrzeb i preferencji, jak również do potrzeb i preferencji tej grupy społecznej, w jakiej funkcjonujemy. Historia i osobiste doświadczenia dają nam wystarczającą ilość dowodów na to, że są osoby, które z uporem maniaka trwają przy raz przyswojonych obrazach świata $w$ ich niezmienionej treści, uporczywie doświadczając psychologicznych trudności z ich adaptacją do nowych obrazów świata funkcjonujących w kulturze ${ }^{34}$. We współczesnej kulturze całkiem sporo jest tzw. konserwatywnych obrazów świata bazujących na podretuszowanym filozoficzną interpretacją poznaniu potocznym (zdroworozsądkowym), które nie liczą się z dobrze potwierdzonymi faktami naukowymi. Przykładem może być pełen uproszczeń obraz świata obrońców płaskiej ziemi, w który jego zwolennicy święcie wierzą, że jest prawdziwy i odzwierciedla obiektywną naturę świata $^{35}$. W tym kontekście trzeba podkreślić, że idee i przekonania, które

${ }^{31}$ J. Życiński, $W$ kręgu nauki i wiary, Kalwaria 1989; tenże, Elementy filozofii nauki, Tarnów 1994.

${ }^{32}$ Zob. G. Abel, Świat jako znak i interpretacja, thum. W. Małecki, Warszawa 2014.

${ }^{33}$ Socjolog T. Parsons formułuje następującą charakterystykę internalizacji: internalizacja jest to proces przekształcania różnorodnych normatywnych aspektów kultury społeczeństwa otaczającego daną jednostkę w nieodłączną część struktury osobowości. Dodałbym nie tylko aspektów normatywnych, ale też i deskryptywnych, odnoszących się do tego jak zbudowany jest świat, i jak należy w nim funkcjonować. Na skutek internalizacji elementy zewnętrzne stają się elementami wewnętrznymi, określają myślenie i motywacje podmiotu. Zob. T. Parsons, Struktura społeczna a osobowość, tłum. M. Tabin, Warszawa 1969.

${ }^{34}$ Zob. Szerzej na ten temat piszą: M. Heller, Przeciw fundacjonizmowi, w: tenże, Filozofia i wszechświat, Kraków 2006, s. 82-101; M. Hohol, B. Brożek, Homo fundamentalis, https://www. miesiecznik.znak.com.pl/homo-fundamentalis/ [dostęp: 2.05.2021]; M. Kossowska, Umyst niezmienny. Poznawcze mechanizmy sztywności, Kraków 2005.

${ }^{35}$ Flat Earth Society, także International Flat Earth Research Society, https://www.tfes.org/ [dostęp: 2.05.2021]. Zob. na stronie https://www.tfes.org/library.php znajduje się cała dostępna 
nabywamy nawet $\mathrm{w}$ młodym wieku, choćby były to idee najbardziej rewolucyjne, $\mathrm{z}$ biegiem czasu dzięki pamięci utrwalają się w umyśle i stają się konserwatywne $^{36}$. Nawet te, jakby się wydawało, z początku rewolucyjne obrazy świata po jakimś czasie utrwalają się w świadomości społecznej i stają się nieprzejednanymi bastionami konserwatyzmu. Utrwalone $\mathrm{w}$ umyśle obrazy świata nie adaptują się tak szybko do zmieniających się warunków kulturowych i społecznych, a także naukowych, które związane są z różnymi zmianami paradygmatycznymi. Wobec konserwatywnych obrazów świata tzw. twarde fakty naukowe również są bezsilne. Mówiąc o akceptacji określonego obrazu świata, trzeba mieć na uwadze, że „zarówno poglądy poznawcze, jak i idee kierownicze kształtują się w czyimś umyśle najpierw i w sposób przemożny pod wpływem tradycji - przez proces uczenia się i nauczania - to znaczy pod wpływem potrzeb i doświadczeń minionych pokoleń" ${ }^{37}$. Okazuje się zatem, że to określone siły i zapotrzebowania społeczne (np. religijnych grup społecznych) wyrażające się w sytuacji danego pokolenia wpływają na kierunek, akceptację, trwałość lub nietrwałość określonego obrazu świata. Obrazy świata są także nośnikami treści aksjologicznych, które mają ważne znaczenie dla realizacji potrzeb grup społecznych. Wpływają na umysł, emocje, na tzw. podniety umysłowe, wzbudzają określone potrzeby, racjonalizują decyzje i wybory, przywołując obowiązujące w grupie wartości i normy. Idee moralne danej wspólnoty, można powiedzieć, zostają odzwierciedlone w akceptowanym przez przyszłego filozofa obrazie świata. Kontynuując swoje badania, Pieter wprost podkreśla, że ,idee są - ze względu na naturę pamięci - konserwatywne i raczej z opóźnieniem przystosowują się do potrzeb społecznych" 38 . Dlatego też naciski społeczne, wyrażające się czy to w presji argumentacyjnej, czy nawet presji fizycznej, jak miało to miejsce w systemach totalitarnych, nie powodują automatycznej zmiany jego obrazu świata na drugi. Sam problem porzucenia jednego obrazu świata na rzecz innego nie wypływa $\mathrm{z}$ racjonalnej decyzji. Jest to kwestia pewnej konwersji, związanej z nawróceniem się na nową wizję rzeczywistości, w której zaczynają realnie istnieć określone elementy, niedostrzegane $\mathrm{z}$ perspektywy odrzuconego obrazu świata. Poza tym, na co zwracają uwagę socjologowie filozofii, a co bezwzględnie można odnieść do filozofa chrześcijańskiego ,splot nawyków, w ich obrębie

bibliografia na ten temat. Zob. K. Jodkowski, Klasyfikacja stanowisk kreacjonistycznych, „Filozoficzne Aspekty Genezy" 2-3 (2005-2006), s. 241-269.

${ }^{36}$ Aby zrozumieć psychologiczne mechanizmy związane z akceptacją obrazów świata, a zwłaszcza dotyczące trudności z ich zmianą, warto by skorzystać z analiz tzw. mechanizmów sztywności poznawczej. Zob. M. Kossowska, Umyst niezmienny... Poznawcze mechanizmy sztywności, Kraków 2005; M. Rokeach, Umyst zamknięty i otwarty, tłum. E. Wojtych, Warszawa 2019.

${ }_{37}$ J. Pieter, Światopogląd humanisty, s. 111.

${ }^{38}$ Tamże, s. 113. 
przekonań, wśród nich uprzedzeń intelektualnych, jakie w okresie wychowawczym opanowują każdego, powoduje, że nawet wysoce krytyczne rozważania myśliciela dojrzałego noszą do pewnego stopnia znamiona jego środowiska z lat dziecięcych i młodzieńczych, z lat bezkrytycznych" 39 . Natomiast specjalistyczne - jeśli można tak powiedzieć - obrazy świata funkcjonujące w ramach naukowych i filozoficznych tradycji badawczych przyswajamy poprzez edukację naukową i filozoficzną na uniwersytecie, w akademii czy też w innych instytucjach naukowych. Przyswajamy zdania stwierdzające określone stany rzeczy uznane za prawdziwe oraz wzorce formułowania i rozstrzygania problemów, które wymyślili i w praktyce utrwalili twórcy danej tradycji. Przyswajamy je zawsze na bazie potocznego obrazu świata, który w porządku ontogenezy poznania jest bazowy dla ludzkiego doświadczania świata i nabywania innych, bardziej wyrafinowanych obrazów świata ${ }^{40}$.

Obraz świata akceptowany przez filozofów chrześcijańskich moglibyśmy opisać w kategorii metafory pola sił, którą spopularyzował znany i bardzo wpływowy w swoim czasie filozof analityczny Willard Van Orman Quine ${ }^{41}$. W tej optyce obraz ten byłby zbiorem założeń i przekonań o różnym statusie epistemologicznym. Byłyby w nim takie przekonania, z których moglibyśmy łatwiej rezygnować, np. pod wpływem zgromadzonych danych empirycznych lub argumentów konceptualnych, ale też występowałyby w nim i takie przekonania, które pozostawałyby nieczułe na jakiekolwiek argumenty empiryczne i konceptualne. Ich odrzucenie lub radykalna reinterpretacja wiązałaby się bowiem z podważaniem określonych twierdzeń bazowych, np. zdania Bóg istnieje, czy dusza istnieje. Są to konserwatywne idee i przekonania, które łatwo nie poddają się żadnej presji zewnętrznej. Za ich akceptacją nie stoi tylko racjonalne uzasadnienie, ale wiara, która $\mathrm{z}$ epistemicznego punktu widzenia znacznie silniej niż odwołująca się do reguł logiki argumentacja, zabezpiecza owe przekonania przed krytyką i odrzuceniem. Wiara bowiem ma silne zdolności immunizacyjne, których sama w sobie nie ma żadna racjonalna argumentacja. Wydaje się, że owe tezy bazowe stanowią bufor zabezpieczający

39 Tamże, s. 112.

${ }^{40}$ Zob. L. Wittgenstein, O pewności, tłum. W. Sady, Warszawa 2014.

${ }^{41}$ Zob. W. Quine, Dwa dogmaty empiryzmu, w: tenże, Z punktu widzenia logiki. Dziewięć esejów logiczno-filozoficznych, tłum. B. Stanosz, Warszawa 2000. Autor pisał tak: „[...] nauka jako całość podobna jest do pola siły, którego warunkami brzegowymi jest doświadczenie. Konflikt $\mathrm{z}$ doświadczeniem na brzegach pola powoduje odpowiednie przystosowania w jego wnętrzu. Niektórym ze zdań zostaje przypisana inna wartość logiczna. [...] Pole jako całość jest jednak na tyle niezdeterminowane przez swoje warunki brzegowe, tj. przez doświadczenie, że istnieje znaczna swoboda wyboru zdań, które wobec danego konfliktu z doświadczeniem mają być «przecenione». Żadne poszczególne świadectwo doświadczenia nie jest związane z jakimś określonym zdaniem z wnętrza pola; związek ten ma co najwyżej charakter pośredni, za sprawą równowagi pola jako całości”. Tamże, s. 72. 
tożsamość przedmiotową danej tradycji. W ich akceptacji chodziłoby nie tylko o uzasadnienie pragmatyczne, ale też o wykazanie, że ich odrzucenie prowadziłoby do radykalnej merytoryczno-treściowej rewizji obrazu świata prowadzącej do zerwania z obowiązującą tradycją. Przed takimi posunięciami można się jednak bronić, stosując np. określone heurystyki. Mogą mieć charakter pozytywny lub negatywny. Heurystyki pozytywne pokazują nam, w jaki sposób mamy myśleć, jak dbać o spójność obrazu świata, jak asymilować do niego nowe przekonania, tak aby nie zagrażały twardemu rdzeniowi tradycji. Natomiast heurystyki negatywne zakazują nam prowadzenia badań w określonym kierunku. Heurystyki mogą być formułowane w postaci dyrektyw stabilizujących myślenie. Mówią one, czego nie należy robić, aby nie doprowadzić do rozbicia tożsamości obrazu świata, bronią nienaruszalności twardego rdzenia, dostarczają dodatkowych strategii argumentacyjnych, aby wzmocnić przedmiotowe konsekwencje akceptowalnego obrazu świata. Heurystyki mogą być także zinstytucjonalizowane. I dotyczy to tak heurystyk pozytywnych, jak i negatywnych. Przykładem może być tzw. negatywna norma wiary, która na mocy instytucjonalnych dekretów zakazuje dokonywania określonych reinterpretacji jako po prostu niezgodnych z kanoniczną (bo właśnie zinstytucjonalizowaną) interpretacją określonych prawd objawienia chrześcijańskiego. Negatywna norma wiary, choć rządzi się pewną wewnętrzną logiką, może być wyrażona za pomocą zinstytucjonalizowanych form, które kształtują świadomość teologów i filozofów. W ten sposób zawiązuje ona pewną formę świadomości metodologicznej. $Z$ różnymi heurystykami spotykamy się dosyć wcześnie, bo już na etapie procesów wychowawczych. Rodzina jako podstawowa komórka wychowawcza pokazuje przecież, w co przyszły adept filozofii ma wierzyć, a w co nie, co uznawać za słuszne, a co nie. Stosuje zatem mniej lub bardziej rozwinięte strategie heurystyczne. Filozof chrześcijański zobligowany jest to akceptowania Magisterium Kościoła oraz innych instytucji z nim powiązanych, które stawiają sobie za cel ochronę integralności określonej wykładni chrześcijańskiego obrazu świata, właśnie za pomocą różnych heurystyk. Instytucje te bowiem dysponują już bardziej wyspecjalizowanymi dla swojego gatunku np. heurystykami negatywnymi (wyrażającymi się w cenzurowaniu sprzecznych z normą wiary prac), których działanie może być szczególnie dotkliwe w wymiarze społecznym i psychologicznym dla tych, którzy przejawiają tendencję do zbyt odważnego stylu myślowego. Dobrym przykładem może być słynny Indeks ksiag zakazanych (Index librorum prohibitorum), w którym znalazły się prace niektórych filozofów i twórców nowożytnej nauki.

Podsumowując, należy stwierdzić, że w taki właśnie sposób - co niektórym może wydać się kontrowersyjne, a nawet obrazoburcze - obraz świata przyswaja sobie każdy filozof chrześcijański. Cały ten proces ma swoją 
genezę w określonym wychowaniu, które dokonuje się w sprzyjającym społecznie i kulturowo kontekście dla akceptacji chrześcijańskiego obrazu świata. Obraz ten po prostu przejmuje od swoich mistrzów i nauczycieli, którzy już wcześniej uznali go za prawdziwy. To jednak, jak długo będzie go akceptował, zależy przede wszystkim od wpływu określonych czynników wewnętrznych i zewnętrznych.

$\mathrm{Z}$ punktu widzenia socjologii filozofii $\mathrm{w}$ całym tym procesie nie ma niczego zaskakującego. Dla filozofa chrześcijańskiego nastawionego obiektywnie i aletycznie do rzeczywistości powyższa analiza mechanizmów społecznych może być matecznikiem dla głoszenia relatywizmu.

\section{Uwagi o instytucjonalizacji obrazu świata}

Chciałbym teraz poświęcić kilka zdań sprawie bardzo ważnej dla socjologa filozofii, mianowicie instytucjonalizacji obrazu świata ${ }^{42}$. Przypomnę tylko, że filozofia jako nauka „obejmuje jakiś kompleks złożony z ludzi zwanych naukowcami, instytucji naukowych oraz stosownych działań indywidualnych czy grupowych wraz z ich rezultatami”" ${ }^{43}$ I choć status metodologiczny filozofii, w tym także filozofii chrześcijańskiej, jest stale kwestionowany i podawany w wątpliwość, nie ulega kwestii, że jest ona instytucją, w której zachodzą określone interakcje między naukowcami, procesy instytucjonalizacji wiedzy, czyli wytworów poznania poszczególnych naukowców lub całych grup badaczy. Jeśli chodzi o samo pojęcie instytucjonalizacji, które na gruncie nauk społecznych mieni się różnymi znaczeniami, to na przebieg dalszych analiz przyjmuję za teoretykiem socjologii Edwardem Shilsem następujące jej projektujące określenie:

Przez instytucjonalizację działalności intelektualnej rozumiem relatywnie częste interakcje osób, które prowadzą tę działalność w ramach układu społecznego, układu który ma granice, wytrzymałość i nazwę. Interakcje posiadają strukturę. Im bardziej intensywne, tym bardziej ich struktura zapewnia pozycję autorytetu, który podejmuje decyzje odnośne szacowania wartości, ich akceptacji, promocji i umiejscowienia; władza ta również ustanawia kryteria wyboru szczególnych tradycji, które mają być rozwijane przez nauczanie i badania. Nie musi istnieć konieczny formalny wymóg odnośnie kryteriów, mogą one i na ogół są zawarte

${ }^{42}$ Szerzej na temat instytucjonalizacji zob. M. Malikowski, Instytucjonalizacja, dezinstytucjonalizacja a zmiana społeczna, „Ruch Prawniczy, Ekonomiczny i Socjologiczny” LIII (1991), z. 3, s. 133-143.

${ }^{43}$ J. Woleński, Dwa pojęcia nauki: metodologiczne i socjologiczne, „Prace Komisji Historii Nauki” 9 (2009), s. 172. 
w praktyce autorytetów - w tym przypadku tych, którzy są najbardziej wybitni intelektualnie. Wysoki stopień instytucjonalizacji działalności intelektualnej zawiera nauczanie i poszukiwania badawcze w obrębie uregulowanej, planowanej i systematycznie zarządzanej organizacji ${ }^{44}$.

Myślę, że opisane mechanizmy instytucjonalizacji realizowane są na bieżąco przez profesjonalnych filozofów, którzy tworzą katedry, instytuty, wydziały, kolegia, fundacje, towarzystwa tylko po to, aby nadać uprawianej przez siebie dyscyplinie społecznie pożądaną strukturę. W ramach tych struktur prowadzą zdeterminowane regułami interakcje, których rezultatem są wymierne liczbowo efekty pracy w postaci publikacji, konferencji, sympozjów itp. Filozofia może zyskiwać określone wsparcie od instytucji religijnych czy państwowych. Nierzadko bowiem sami filozofowie, nie mogąc zapewnić filozofii pożądanej pozycji, a sobie określonych profitów z tego wynikających, poszukują wsparcia - co dziś jest chyba na porządku dziennym - w instytucjach mocniejszych i społecznie bardziej stabilnych, korzystając z ich legitymizacji, zmierzają tym samym do podniesienia prestiżu społecznego filozofii. Funkcjonujący w ramach tradycji filozofii chrześcijańskiej obraz świata był w ciągu wieków poddawany stopniowej, ale za to bardzo konsekwentnej instytucjonalizacji. Nie chcę wchodzić w pewne niuanse historyczne, które ją zainicjowały, ograniczę się tylko do - być może - lapidarnego stwierdzenia, że była ona zamierzona, albowiem miała na celu zabezpieczenie doktryny chrześcijańskiej przed deformacjami wypływającymi z różnych nowo powstających denominacji chrześcijańskich. Instytucjonalizacja ta znalazła wyraz przede wszystkim w oficjalnych dokumentach nauczania Kościoła Rzymskokatolickiego, np. soborach powszechnych, jak Trydencki czy Vaticanum Primum. Przykładem są również encykliki, np.: Aeterni Patris ${ }^{45}$ czy Fides et ratio ${ }^{46}$. W tekstach tych znajdujemy nie tylko zalecenia, jak powinno się uprawiać teologię i filozofię chrześcijańską, ale mamy też zarysowany kształt obrazu świata, za jakim opowiadali się papieże. Niektórzy nawet wprost utożsamiali filozofię i teologię chrześcijańską z konkretną formacją metafizyczną (obrazem świata), która dominowała w określonym czasie historycznym i była legitymizowana przez czynniki instytucjonalne, a bywało, że i polityczne, które w podtrzymywaniu jednolitego obrazu świata widziały skuteczne narzędzie społecznej kontroli.

${ }^{44}$ E. Shils, The Calling of Sociology and Other Essays on the Pursuit of Learning. The Selected Papers of Edward Shils, t. 3, Chicago 1980, s. 165, cyt. za: N. Kraśko, Instytucjonalizacja socjologii $w$ Polsce 1970-2000, Warszawa 2010, s. 10.

${ }^{45}$ Encyklika Leona XIII, Aeterni Patris, Warszawa 2003.

${ }^{46}$ Encyklika Fides et ratio Ojca Świętego Jana Pawła II do biskupów Kościoła katolickiego O relacjach między wiarą i rozumem, nr 1. Tekst polski wydany przez Pallottinum, Poznań 1998. 
Dominującym obrazem świata $\mathrm{w}$ dwudziestowiecznej filozofii chrześcijańskiej był obraz zbudowany na założeniach neotomizmu. Stanowił on pogłębioną filozoficznie interpretację zdroworozsądkowego obrazu świata. Już bowiem po tzw. rewolucji scholastycznej XIII wieku uznano, że tylko tomistyczny obraz świata - w przeciwieństwie do platońsko-augustyńskiego ujmuje prawdziwą naturę rzeczywistości. Jego przesłanki metafizyczne oficjalnie uznano za tzw. przedsionki wiary ${ }^{47}$. Tak właśnie było w przypadku wpływowego neotomizmu, który w XIX wieku został uznany przez papieża Leona XIII za wzór do opracowania filozofii i teologii chrześcijańskiej. Wprawdzie zalecano tomizm jako podstawę twórczego rozwijania filozofii chrześcijańskiej, ale zalecenie to brano na tyle poważnie, że tratowano je w kategorii bezwzględnego obowiązku. Neotomizm uznano za zdrową filozofię, na bazie której mogła być rozwijana tylko zdrowa teologia i zdrowa filozofia chrześcijańska. Tym samym zadekretowano, że tylko neotomistyczny obraz świata odzwierciedla prawdziwą naturę rzeczywistości, i tylko w jego optyce może dokonać się adekwatna interpretacja objawienia chrześcijańskiego, która swój wyraz znalazła w dogmatycznej teologii spekulatywnej. Dominującej roli tomistycznego obrazu świata w teologii i filozofii chrześcijańskiej nie kwestionował także papież Jan Paweł II. Wskazywał on jednak na konieczność jego uzupełnienia zdobyczami filozofii i nauki współczesnej. Odczuwał wyraźną potrzebę otwarcia tomistycznego obrazu świata na zdobycze ducha współczesności, przed którymi wielu filozofów chrześcijańskich przeżywa do dziś nieuzasadniony lęk.

Wielu myślicieli głosiło z niemałą dozą oczywistego radykalizmu, że fundamentów wiary chrześcijańskiej można bronić tylko w ramach wiarygodnego obrazu świata, za którym stał heroiczny autorytet samego Akwinaty, który łamiąc wszelkie zakazy i ograniczenia w studiowaniu Stagiryty, wykorzystał jego naturalistyczną filozofię do opracowania gigantycznej i wiekopomnej syntezy teologiczno-filozoficznej ${ }^{48}$. Wielu myślicieli przekonywało wówczas, ale i przekonuje obecnie, że wyłącznie w ramach tak realistycznie opracowanego obrazu świata da się przeprowadzić spójną interpretację chrześcijańskiego doświadczenia. Świat rzeczywisty bowiem jest taki, jaki jest jego

${ }^{47}$ Obecnie odchodzi się do poszukiwania tzw. przedsionków wiary: „To, że chrześcijaństwo od swego początku rozwijało się w szczególnej bliskości rozumu filozoficznego pozwala nam podjąć problem racjonalnej odpowiedzialności za wiarę w poczuciu związku z całą dotychczasową tradycją myślenia teologicznego. Nie chodzi jednak o poszukiwanie czegoś w rodzaju filozoficznego preambula fidei, co najpierw trzeba zdobyć, aby rozumnie (odpowiedzialnie) uwierzyć, a następnie beztrosko porzucić na rzecz «czystej» wiary. Wiara pozbawiona permanentnego namysłu krytycznego nie staje się przez to «lepszą wiarą», może natomiast przerodzić się w swoje przeciwieństwo: zabobon i wróżbę”. K. Śnieżyński, W poszukiwaniu nowego oblicza wiary w epoce po-metafizycznej, „Teologia Praktyczna” 9 (2008), s. 156.

${ }^{48}$ Zob. S. Swieżawski, Dzieje europejskiej filozofii klasycznej, Warszawa 2000. 
tomistyczny obraz. Konkurencyjne obrazy świata, wypracowane w innych tradycjach badawczych, mniej lub bardziej deformują rzeczywistość, wprowadzając do niej elementy aprioryczne wykluczające $\mathrm{w}$ punkcie wyjścia realizm ludzkiego poznania, a przecież to realizm tomistyczny określa autentyczność wiary ${ }^{49}$. W ten sposób obraz świata zaczął determinować tożsamość wiary: jaki obraz świata, taka też wiara. Pokaż mi swój obraz świata, a powiem ci, jakim jesteś wierzącym - powiadali niektórzy, domagając się w ten sposób nie tyle świadectwa wyznawanej wiary, ile świadectwa wyznawanego obrazu świata. Stąd też pojawiające się niekiedy w różnych okolicznościach i gremiach społecznych ironiczne sformułowanie: prawowicie wierzącym może być tylko ten, kto jest wyznawcą tomistycznego obrazu świata.

Sytuacja taka nie mogła jednak trwać w nieskończoność. Mechanizmy instytucjonalne okazały się bezskuteczne wobec napływu nowych idei. W ubiegłym stuleciu niektórzy polscy filozofowie, jak np. ks. Antoni Siemianowski ${ }^{50} \mathrm{~W}$ latach sześćdziesiątych czy ks. Józef Tischner ${ }^{51} \mathrm{w}$ latach siedemdziesiątych i osiemdziesiątych wykazywali, że tomistyczny obraz świata, z którym związała się teologia i filozofia chrześcijańska, przyczynił się do głębokiego kryzysu katolicyzmu. Lekarstwa na kryzys upatrywali w odrzuceniu tomistycznego obrazu świata i wprowadzeniu na jego miejsce obrazu utkanego z idei i przekonań wywodzonych z fenomenologii, hermeneutyki i filozofii dialogu. Zainicjowana prowokacyjnym wystąpieniem ks. Siemianowskiego i ks. Tischnera dyskusja, świetnie pokazuje, jakie mechanizmy psychologiczne i socjologiczne rządzą akceptacją i odrzuceniem określonego obrazu świata. Stąd też można powiedzieć, że spór o rolę tomistycznego obrazu świata $\mathrm{w}$ interpretacji wiary i moralności chrześcijańskiej dostarczył

${ }^{49}$ Anonimowy recenzent formułuje bardzo ważne pytania, na które odpowiedź mogłoby stanowić osobne studium. Oto te pytania: „Ile wiary jest w religijnej wierze oraz czy w świetle poczynionych w artykule ustaleń można jeszcze w ogóle zasadnie mówić o religijnej wierze. Czy przypadkiem nie jest tak, że wiarą nazywamy przyjmowany w ramach danej organizacji religijnej i koncesjonowany przez nią obraz świata? Pytania te odniesione do wiary religijnej dotyczą tego, w co my tak naprawdę wierzymy, w Boga czy w obraz Boga, który w procesie socjalizacji religijnej został nam przekazany przez wspólnotę wierzących". Nie chcę tej kwestii w tym momencie ostatecznie rozstrzygać, ale bardziej skłaniałbym się ku odpowiedzi, że dokonujemy zawierzenia w pewien obraz świata, który przyjmujemy podczas edukacji religijnej. Nie mamy przecież bezpośredniego doświadczenia Boga. Jesteśmy w tej kwestii jakby skazani na socjalizację religijną oraz jej jakość, z którą różnie bywa. Stąd też nasze poznanie transcendencji jest z konieczności zapośredniczone obrazami świata. Oczywiście wymaga to głębszego uzasadnienia, ale sam problem jest ważny z punktu widzenia refleksji nad wiarą religijną.

${ }^{50}$ Zob. A. Siemianowski, Spór o aktualna wartość tomizmu, „Więź” 1963, nr 11-12, s. 30-39, szerzej pisze o tych wczesnych sporach wokół tomizmu M. Tyl, Zapomniany spór o tomizm, „Folia Philosophica" 40 (2018), s. 5-15.

${ }^{51}$ Zob. J. Tischner, Schylek chrześcijaństwa tomistycznego, „Znak” 1970, nr 1, s. 1-20; tenże, Myślenie wobec wartości, Kraków 1993. 
więcej informacji o samych dyskutantach, zwłaszcza o ich emocjach i wzajemnym stosunku do siebie, niż o problemach filozoficznych. Spór ten musiał rozczarować tych wszystkich, którzy spodziewali się, że któraś ze stron zostanie przekonana przez stronę przeciwną ${ }^{52}$. Te socjologiczne i psychologiczne uwagi oczywiście nie mówią nam niczego na temat prawdziwości lub fałszywości głoszonych tez. Pozwalają jednak zrozumieć, jak bardzo podmiotowe postawy, ukształtowane przez wychowanie (wpajanie określonych idei, norm moralnych) w określonej tradycji, edukację uniwersytecką (np. seminaryjną), a także lęki i obawy przed różnymi, czasem sztucznie wykreowanymi duchami współczesności - tak zresztą do dziś mało doceniane przez filozofów chrześcijańskich - rozstrzygają o akceptacji danego obrazu świata, pokazują, jak bardzo ludzie wierzą w określony obraz świata wyniesionego $\mathrm{z}$ tradycji filozoficznej, do której przed laty, mniej lub bardziej świadomie, zgłosili swój akces, i jak bardzo psychologicznie przyzwyczajają się do niego. Obrazy świata rzeźbią koleiny w naszych mózgach, sprawiając, że bardzo trudno jest nam z tych kolein się wydostać i spojrzeć na rzeczywistość epistemicznie nieuprzedzonym okiem.

Stopniowa recepcja fenomenologii, hermeneutyki i filozofii dialogu, do której w dużym stopniu przyczynili się i ks. Siemianowski, i ks. Tischner, nie doprowadziła jednak do całkowitego wyrugowania tomistycznego obrazu świata. Z socjologicznego punktu widzenia kiełkujące w ramach tradycji filozofii chrześcijańskiej nowe obrazy świata nie miały łatwej adaptacji w kulturze filozofowania zdominowanej przez zinstytucjonalizowany obraz tomistyczny. Zwolennicy tomistycznego obrazu świata, który został uznany za podstawową ramę interpretacyjną dla filozofii chrześcijańskiej, od samego początku krytycznie odnosili się do wszystkich prób konceptualizacji filozofii chrześcijańskiej w terminologii zapożyczonej z fenomenologii, hermeneutyki

${ }^{52}$ Zob. D. Kot, Historia pewnego rozczarowania. Spór Tischnera z tomistami, https://www. miesiecznik.znak.com.pl/kot-historia-pewnego-rozczarowania-spor-tischnera-z-tomistami/ [dostęp: 28.04.2021]. Autor tak podsumowuje swoje analizy rzeczonego sporu: „Ta naiwność została jednak szybko rozbrojona. I spór z tomistami dokładnie pokazuje, w którym miejscu moje wyobrażenie zawiodło. Zakładałem ponadparadygmatyczny horyzont, w granicach którego znajduje się cała filozofia i każde racjonalne myślenie. Zamiast tego musiałem uznać, że istnieją nieprzenikające się nawzajem paradygmaty lub - używając innej terminologii - filozoficzne narracje. I być może w ramach tych partykularnych szkół czy kierunków możliwy jest jakiś rzeczowy i owocny spór, ale debata pomiędzy nimi może mieć za cel co najwyżej próbę wypowiedzenia własnych stanowisk. Odrębne języki, własna siatka pojęć, przyjmowane explicite i implicite wartości oraz aksjomaty sprawiają, że zamiast jednego żywiołu myślenia mamy do czynienia z osobnymi, nieprzenikalnymi i impregnowanymi na dialog myśleniami. Ich racją istnienia jest, poza wszystkim innym, przekonanie, że tylko one są prawdziwym myśleniem. Pobłażliwość dla niepoważnych adwersarzy brałem za uprzejmość wobec równorzędnych partnerów sporu”. Można tylko dopowiedzieć, że dyskusja nie mogła się zakończyć żadnym rozstrzygnięciem, gdyż każda ze stron tego sporu tkwiła w swoim własnym obrazie świata. 
czy filozofii dialogu. Na przykładzie rodzimego środowiska możemy pokazać, że siła przemian społecznych i kulturowych spowodowanych intensywnym rozwojem nauki i techniki, zwłaszcza ich wpływem na filozofię, doprowadziły do znacznego osłabienia wpływu neotomistycznego obrazu świata na filozofię chrześcijańską, a w konsekwencji do znacznego zbalansowania innych obrazów świata w łonie tradycji filozofii chrześcijańskiej. Już bowiem w latach osiemdziesiątych i dziewięćdziesiątych wykrystalizowała się inna koncepcja filozofii chrześcijańskiej, bardziej czuła na wpływy nauk szczegółowych. Można ją nazwać filozofią chrześcijańską w kontekście nauki, choć sami jej zwolennicy nazywają ją np. pozytywizmem chrześcijańskim lub naturalizmem chrześcijańskim $^{53}$. Filozofujący w nauce argumentują, że błędem dotychczasowej filozofii chrześcijańskiej było zbyt kurczowe trzymanie się tomistycznego obrazu świata, który w konfrontacji z szybko rozwijającymi się naukami empirycznymi nie wytrzymał krytyki. Choć obraz ten uzyskał silne wsparcie instytucjonalne ze strony Kościoła Katolickiego, o czym świadczy jego obecność w aktualnie obowiązującym Katechizmie Kościoła katolickiego, to jednak nie wywalczył sobie żadnego poczytnego miejsca we współczesnej kulturze naukowej (formowanej przez osiągnięcia nauk przyrodniczych), został bowiem radykalnie zdyskredytowany przez instytucjonalną naukę ${ }^{54} . \mathrm{Z}$ tomistycznym obrazem świata nie dyskutowano, obraz ten pozostawiono, zastępując go innym, tzw. naukowym obrazem świata.

$\mathrm{Z}$ punktu widzenia socjologii filozofii instytucjonalizacja tomistycznego obrazu świata tylko częściowo zabezpieczyła go przed refutacją. Rewolucja metanaukowa i przełomowe odkrycia dokonane w naukach przyrodniczych doprowadziły do wykrystalizowania się tzw. naukowego obrazu świata ${ }^{55}$, który przyczynił się do podważenia wielu założeń filozofii chrześcijańskiej opartej na tezach zdroworozsądkowego obrazu świata. Generalnie rzecz ujmując, kwestia instytucjonalizacji tradycji badawczej a także akceptowanego przez jej członków obrazu świata jest bardzo interesująca z socjologicznego punktu widzenia. Szczegółowe przebadanie tych problemów, które chciałbym tylko zasygnalizować, mogłoby wykazać, w jaki sposób czynniki pozapoznawacze (np. pragmatyczne, związane z utrzymaniem przez instytucję Kościoła określonej pozycji społecznej, reguły internalizacji obrazu świata, które determinują określone autorytety instytucjonalne) rozstrzygały o akceptacji rozwiązań określonych problemów empirycznych i konceptualnych (przykładem może być tutaj sprawa tzw. Galileusza czy Karola Darwina), a tym samym decydowały, w ramach jakiego obrazu świata może być kształtowana prawdziwa i autentyczna artyku-

${ }^{53}$ Zob. J. Życiński, Transcendencja i naturalizm.

${ }_{54}$ M. Heller, Naukowy obraz świata a zadanie teologa, s. 13-28.

${ }_{55}$ Zob. M. Lubański, Uwagi w sprawie tzw. naukowego obrazu świata, w: Obrazy świata w teologii i naukach przyrodniczych, s. 28-42. 
lacja chrześcijańskiego doświadczenia. I znów socjologia filozofii pozwala nam dostrzec pewne mechanizmy rządzące odrzuceniem starych i akceptacją nowych obrazów świata. Cytowany poprzednio Józef Pieter uważa, że

życie dokonuje weryfikacji przekonań światopoglądowych [obrazów świata - dod. P.D.] już mniej więcej ukształtowanego filozofa. To znaczy - dokonuje odsiewu przekonań filozoficznych, niedopowiadającym interesom społecznym danej grupy czy klasy. Stopniowo nierzadko na drodze sporów, dokonuje się przystosowanie określonego układu przekonań filozoficznych do układu potrzeb danej klasy w jej położeniu bieżącym lub danego (mniejszego) ugrupowania społecznego ${ }^{56}$.

Zdarzyło się to w czasach nowożytnych w XVII wieku, kiedy uległ erozji arystotelesowski obraz świata. Przez długie wieki dostarczał on całym pokoleniom myślicieli narzędzi do rozumienia i oswojenia kosmosu. Tymczasem grupie naukowców, którzy tworzyli podstawy nowożytnej fizyki, obraz ten przestał cokolwiek tłumaczyć. Za jego pomocą nie dało się już oswoić wszechświata. Zapotrzebowania poznawcze i pozapoznawcze nowożytnych przyrodników kierowały się $\mathrm{w}$ stronę innego obrazu świata, którego struktury nie wyznaczała już spekulatywna metafizyka bytu, tylko matematyka, a dokładnie rzecz ujmując, metoda matematyczno-empiryczna, która od XVII wieku stała się obowiązującą metodą uprawiania nauk przyrodniczych. Zastosowanie jej w naukach empirycznych przysporzyło im niebywałego sukcesu. W przeciwieństwie do fizyki Arystotelesa, która koncentrowała się na zjawiskowym aspekcie bytu, nowa fizyka odsłoniła przed badaczami takie jego obszary, które doprowadziły do załamania się obrazu świata zbudowanego ze zdroworozsądkowych wyobrażeń. Nowy, naukowy obraz świata musiał doprowadzić do gruntownej reformy myślenia, oczywiście nie obyło się oporów, czego dobitnym przykładem jest szeroko komentowana sprawa Bruna czy Galileusza. Nowatorskie koncepcje astronomiczne tego ostatniego osądzono w imię zasad opartej na zdrowym rozsądku metafizyki Stagiryty, wspieranej w owym czasie przez instytucje kościelne. Francuski historyk nauki Alexandre Koyré twierdzi, że twórcy nauki nowożytnej

musieli zniszczyć świat i zastąpić go innym. Musieli oni zreformować strukturę samego naszego myślenia, stworzyć na nowo i poddać rewizji pojęcia, jakimi to myślenie się posługuje, spojrzeć na byt w zupełnie nowy sposób, wypracować nową ideę poznania i nową ideę nauki, a nawet zmienić ten naturalny

${ }^{56}$ J. Pieter, Światopogląd humanisty, s. 113. 
punkt widzenia, jakim jest zdrowy rozsądek (sens commun) na inny, wcale nie zdroworozsądkowy ${ }^{57}$.

Po prostu stary (nie)naukowy obraz świata nie tylko nie pasował do nowej metody badania i uzyskiwanych za jej pomocą wyników, ale też nie zaspokajał potrzeb poznawczych i emocjonalnych samych naukowców.

W kontekście tego, co zostało powiedziane, związek niektórych filozoficznych wykładni chrześcijańskiej tradycji badawczej z instytucjami kościelnymi staje się jeszcze bardziej zrozumiały. Miał on zapobiegać nadmiernemu wzrostowi wewnętrznego pluralizmu teoretycznego, który związany był z powstawaniem nowych obrazów świata. W instytucjach kościelnych pluralizm był zawsze podejrzany. Kojarzono go wprost z niebezpiecznym relatywizmem, którego konsekwencją jest rozmycie zasad. Zdawano sobie sprawę, czego znów dobitnym przykładem jest sprawa Galileusza, że nowy obraz świata zagraża nie tylko podstawom wiary, ale też prowadzi do niepokojów psychologicznych i anomii określonej grupy społecznej, która normy i reguły moralno-społecznego funkcjonowania uzasadniała, odwołując się właśnie do obrazu świata. Wszak przez bardzo długi czas uważano (zresztą i dziś wielu przyjmuje takie stanowisko), że obraz świata kształtujący tę tradycję powinien być wewnętrznie jednolity i spójny, gdyż tylko wtedy będzie można skutecznie bronić depozytu wiary chrześcijańskiej przed zakusami rewolucyjnych idei. A jeśli tak, to powinno się dążyć do zachowania niezmiennego w swojej treści obrazu świata niezależnie od tego, że nie nadąża on za współczesnymi przeobrażeniami dokonującymi się w kulturze, a zwłaszcza w nauce. Również współcześnie wielu filozofów chrześcijańskich twierdzi, że trzeba być bardzo ostrożnym wobec jakiejkolwiek asymilacji do chrześcijańskiego obrazu świata różnych danych, które przynoszą nauki przyrodnicze czy społeczne, zwłaszcza chyba wobec nie tyle nauk przyrodniczych, ile społecznych, gdyż dokonywane w nich odkrycia podważają szereg tez dotyczących obiektywnej natury ludzkiej i jej funkcjonowania. Stąd też niezmienność obrazu świata starano się zapewnić nie w drodze racjonalnej dyskusji, ale za pomocą administracyjnych zarządzeń, które miały hamować rozwój nowych idei. Sytuacja ta powtarza się i dziś, przykładem są różnego rodzaju opinie, instrukcje, listy, dokumenty kościelne, w których stosuje się negatywne heurystyki zabraniające rozwijać chrześcijański obraz świata $\mathrm{w}$ niebezpiecznym kierunku, który mógłby doprowadzić do jego destabilizacji. Na podstawie lekcji, której udziela nam historia, wiemy, że czasem bardziej wierzono decyzjom niektórych autorytetów, niż doświadczeniu i matematyce, które odkrywały coraz to nowe obszary

${ }^{57}$ A. Koyré, Galilée et Platon, w: Études d'histoire de la pensée scientifique, Paris 1973, s. 171, cyt. za M. Heller, Teologia i wszechświat, s. 44. 
wszechświata i nie pozostawiały złudzenia, że wiara w stary obraz świata jest po prostu bezpodstawna. Czy naprawdę filozofowie chrześcijańscy wyciągnęli naukę z tej lekcji historii? Dobitnym przykładem takiej zabezpieczającej strategii były już XIII-wieczne potępienia filozofii Arystotelesa, które w praktyce i tak nie odniosły zamierzonego skutku. Przecież św. Tomasz z Akwinu wbrew instytucjonalnym autorytetom zaczął studiować pogańskiego Arystotelesa, co znalazło swój finał w stworzeniu, podtrzymywanej do dziś przez wielu filozofów chrześcijańskich, monumentalnej syntezy teologiczno-filozoficznej. Rację ma Robert Poczobut, kiedy pisze, że ,żyjący w XXI wieku odpowiednik Tomasza z Akwinu czy I. Kanta, z równą swobodą jak oni, posługiwałby się dostępną wiedza naukową, w szczególności wiedzą reprezentowaną przez współczesną kognitywistykę" ${ }^{58}$. Aby jeszcze dokładniej wyrazić, o co mi chodzi, przytoczę opinię Piotra Gutowskiego, filozofa ze środowiska KUL-u, o znanym i wpływowym analitycznym filozofie religii Richardzie Swinburnie. Gutowski, podsumowując dorobek Swinburne’a, pisze tak: „«Z ducha» tego rodzaju filozofia przypomina filozofię św. Tomasza z Akwinu. Jest całkiem prawdopodobne, że gdyby Doktor Anielski znał współczesną naukę i filozofię oraz mógł ocenić dorobek filozofów chrześcijańskich XX wieku, za swojego głównego kontynuatora uznałby nie któregoś z tomistów, ale właśnie Richarda Swinburne'a" ${ }^{9}$. Być może jest to wskazówka, aby dążyć do coraz spójniejszej asymilacji chrześcijańskiego obrazu świata z tzw. naukowym obrazem świata. Nie trzymać się zbyt mocno zinstytucjonalizowanych form, które - jak się okazuje - zaczynają rozsypywać się jak domki z kart w konfrontacji z rzeczywistością. Zinstytucjonalizowany obraz świata traci po prostu zmysł rzeczywistości. W tej kwestii Tomaszowy zmysłrzeczywistości może być uznany za wzorcowy, łamie on bowiem instytucjonalne ograniczenia i uprzedzenia wobec nowych idei, które twórczo można spożytkować dla filozofii chrześcijańskiej. Czyż nie to samo zrobił właśnie św. Tomasz, kiedy w XIII wieku starał się wmontować (zresztą z powodzeniem) teologię i filozofię w ramy obowiązującej wówczas arystotelesowskiej koncepcji nauki? Uważam bowiem, że filozofowie chrześcijańscy bezwzględnie powinni pójść śladami św. Tomasza i zacząć uprawiać taką filozofię chrześcijańską, która na poważnie, a nie tylko deklaratywnie, bierze dorobek nie tylko nauk empirycznych, ale też (może zwłaszcza dziś) nauk społecznych i humanistycznych ${ }^{60}$. Chodzi o uprawianie filozofii, która liczy się ze zmysłem rzeczywistości in concreto, a nie tylko in

${ }^{58}$ R. Poczobut, Czynności i władze poznawcze. Dwa ujęcia. Klasyczne i kognitywistyczne, w: Dydaktyka filozofii. Epistemologia, red. S. Janeczek, A. Starościc, Lublin 2015, s. 243-244.

${ }^{59}$ Opinia ta znajduje się na stronie internetowej Wydziału Filozofii Katolickiego Uniwersytetu Lubelskiego: http://www.kul.pl/art_64135.html [dostęp: 3.05.2021].

${ }^{60}$ Zob. pouczający tekst: K. Śleziński, Filozoficzne implikacje zmieniającego się obrazu rzeczywistości przyrodniczej, „Ruch Filozoficzny” LXXV (2019), nr 3, s. 153-167. 
abstracto. Chodzi zatem o promowanie takiego obrazu świata, który bierze pod uwagę całe bogactwo danych niesionych przez różne nauki. Wytworzenie takiego obrazu wymaga przede wszystkim interdyscyplinarnej współpracy różnych grup badaczy, a co najważniejsze - taki obraz świata powinien być przekazywany młodemu pokoleniu, począwszy od najbardziej podstawowych stopni edukacji szkolnej, tak aby ukształtować określony typ mentalności, w której religia i nauka nie stałyby w opozycji ${ }^{61}$. Budowanie chrześcijańskiego obrazu świata musi się dokonywać w nieustannym dialogu z naukami, dlatego już dziś zachodzi pilna potrzeba kształcenia specjalistów, którzy wyposażeni w odpowiednie kompetencje będą umiejętnie przekazywać zgodny z aktualnie obowiązującą wiedzą obraz świata, w którym jest miejsce na transcendencję. Sprawy te wymagają jednak głębszego przemyślenia.

Podsumowując, warto podkreślić, iż historia uczy nas, że wszelkie instytucjonalne zakazy wcześniej czy później są bezwzględnie łamane, a nowe idee, skutecznie zapładniając umysły badaczy, prowadzą do ukształtowania nowych obrazów świata. Stąd też nie należy się dziwić, że wielokrotnie podejmowano próby - a historia pełna jest stosownych przykładów - aby instytucjonalnie zagwarantować monolityczny charakter obrazowi świata, a tym samym uchronić tradycję filozofii chrześcijańskiej przed zagrażającym jej - w myśl tych interpretacji - wewnętrznym pluralizmem i relatywizmem. Wsparcie instytucjonalne nie zawsze jednak było szczęśliwe. Dyktatorsko pojmowane prowadziło, jak w przypadku sprawy Galileusza czy Darwina, do kompromitacji przedstawicieli instytucji kościelnych, a tym samym przyczyniło się do ukształtowania negatywnego i szkodliwego społecznie stereotypu Kościoła jako instytucji hamującej rozwój nauki.

\section{Uwagi końcowe}

Być może po przeczytaniu tego tekstu wielu filozofów chrześcijańskich stwierdzi, że zawarte w nim tezy i analizy są po prostu trywialne i tak naprawdę niczego głębszego nie wnoszą do sporu o filozofię chrześcijańską. Nawet jeśli wiele z przywołanych tez było już głoszonych przez prominentnych przedstawicieli różnych nurtów filozoficznych, to jednak nie były one głoszone przez filozofów chrześcijańskich, różnych autoramentów, którzy - jak wyraziłem to powyżej - w czynnikach społecznych i kulturowych widzą zagrożenie relatywizacją. Uważam, że filozofowie chrześcijańscy mają pewien opór właśnie

${ }^{61}$ O problemach dotyczących edukacji w kontekście naukowego obrazu świata pisze w swoim tekście M. Słomka. Omawia problem wpływu na edukację szkolną antyewolucyjnego kreacjonizmu. Zob. M. Słomka, Antyewolucyjny kreacjonizm we wspótczesnej Polsce i jego wpływ na edukacje religijna, „Roczniki Filozoficzne” LXVIII (2020), nr 4, s. 133-167. 
przed przyznaniem się do czegoś, co jest trywialne, a co jednak dosyć mocno określa ich sposób filozofowania. Badanie filozofii chrześcijańskiej z perspektywy socjologii filozofii pokazuje, że akceptacja określonego obrazu świata nie polega na kontrolowanej racjonalnie wymianie argumentów. Choć każda filozofia rozwija się według prawideł immanentnej logiki, to jednak określone czynniki społeczne i psychologiczne mają wpływ na to, co dany filozof akceptuje jako oczywiste i niepodlegające żadnej dyskusji. Akceptacja obrazu świata jest konsekwencją wychowania, które dokonuje się w określonej grupie społecznej, wyznającej określone idee aksjologiczne i przekonania deskryptywne ${ }^{62}$. W ten sposób w przyszłym adepcie filozofii, który zawsze pozostaje dzieckiem swojego czasu i kultury, zostaje przygotowany umysłowy i emocjonalny grunt pod akceptację już bardziej spekulatywnego obrazu świata, z którym ów adept zapoznaje się podczas fachowych studiów filozoficznych pod okiem uznawanych przez niego autorytetów. Rację ma Wittgenstein, kiedy pisze: „Ogromnie dużo nauczyłem się i przejąłem od innych, dzięki autorytetowi ludzi, a potem odkryłem pewne rzeczy potwierdzane lub obalane przez moje doświadczenie" ${ }^{63}$. Z właściwą sobie nutą sarkazmu w Uwagach różnych pisał: „W moim myśleniu jak u każdego człowieka, wiszą zaschnięte szczątki moich wcześniejszych obumarłych myśli" ${ }^{64}$, które pochodzą od innych myślicieli. Wpływ na akceptację obrazu świata ma wychowanie. Doprowadza ono do takiego ukształtowania umysłu, który będzie w stanie dokonać

${ }^{62} \mathrm{~W}$ związku z tym pojawia się pytanie, jak dalece akceptacja obrazu świata jest zależna od woli podmiotu, a w jakim stopniu jest zdeterminowana przez czynniki zewnętrze, czyli nie dokonuje się przy udziale woli. Wydaje się, że można by ten problem umieścić w kontekście współczesnej dyskusji na temat woluntaryzmu epistemologicznego. Woluntaryści twierdzą, że podmiot poznający może mieć bezpośredni lub pośredni wpływ na kontrolę akceptowanych przekonań. Tak jak mamy wpływ na nasze wolne działania, tak można mieć wpływ na to, jakie przekonania akceptujemy. Chodzi tu o wolitywną kontrolę niektórych, a nie wszystkich przekonań osoby. Przeciwnicy woluntaryzmu wysuwają argumenty, że uznanie określonych przekonań teistycznych, np. Bóg istnieje, nie jest zależne od woli człowieka. Chrześcijanie przecież wierzą, że do ich akceptacji potrzebny jest czynnik nadprzyrodzony w postaci łaski Bożej. Czyż wobec tego można mówić o pełnej wolności podmiotu? Można powiedzieć, że akceptacja obrazu świata, który przyswajamy sobie w trakcie socjalizacji kulturowej, nie do końca zależy od naszej woli. Po prostu akceptujemy określone przekonania podawane nam przez autorytety wychowawcze i edukacyjne. Ważny jest tutaj epistemiczny komponent zaufania, a na jego bazie kształtuje się podmiotowa wiara, która wyraża się w różnych przeświadczeniach, przyjmowanych początkowo w sposób bezrefleksyjny. Rozwój poznawczy, nowo przyswojona w trakcie edukacji wiedza, mogą powodować świadomą i wolną decyzję o zmianie dotychczasowych przekonań i akceptacji nowych. Wydaje się, że racjonalnym podejściem jest takie, które głosi, że pewne przekonania przyswajamy bez udziału woli, a inne za wyraźną jej aprobatą. Zob. M. Wójtowicz, Współczesna debata wokół koncepcji woluntaryzmu doksastycznego, „Przegląd Filozoficzny - Nowa Seria” R. 21 (2012), nr 2 (82), s. 411-423; T. Vitz, Doxastic Voluntarism, The Internet Encyclopedia of Philosophy, https://iep.utm.edu/home/about/ [dostęp: 2.05.2021].

${ }^{63} \mathrm{~L}$. Wittgenstein, O pewności, s. 45.

${ }^{64}$ Tenże, Uwagi różne, s. 43. 
podmiotowego (osobistego) aktu epistemicznej wiary, przyjmując od innych, jako swój własny, określony obraz świata (chrześcijański), który de facto staje się czymś w rodzaju wyuczonego kognitywnego wzorca widzenia, za pomocą którego dokonuje się stopniowe oswajanie (aspekt hermeneutyczny) rzeczywistości ${ }^{65}$. Dopiero akceptacja obrazu świata umożliwia formułowanie określonych strategii argumentacji logicznej, których zadaniem jest objaśnienie i uzasadnienie przedmiotowych konsekwencji przyjętego obrazu świata ${ }^{66}$. W tym kontekście pomocne może być rozróżnienie na: nabycie przekonania i jego utrwalenie. Nabycie przekonania może dokonać się pod wpływem różnych czynników pozamerytorycznych: emocji, potrzeb, wpływu grupy, konformizmu itp. O tych mechanizmach traktuje właśnie socjologia filozofii. Natomiast argumentacja, a zwłaszcza jej notoryczne powtarzanie, umożliwia utrwalenie nabytych przekonań. Kwestia uzasadnienia i utrwalenia przekonań pozostaje $\mathrm{w}$ gestii epistemologii, która dysponuje kryteriami waloryzacji tez. Ma ona zawsze niezbywalny komponent normatywny. Praktyki argumentacyjne - podkreślmy - opanowuje się poprzez trening pod okiem tych, którzy sami wcześniej już je wypróbowali. W latach siedemdziesiątych filozofowie nauki wskazywali na obecność tzw. wiedzy ukrytej, która funkcjonuje w każdej tradycji badawczej i rozstrzyga o akceptacji tez ${ }^{67}$. Intuicje te celnie

${ }^{65}$ Hermeneutyczne aspekty obrazu świata oraz ich wpływ na samorozumienie współczesnego człowieka podkreśla w swoim artykule: F. Fellman, Samorozumienie nowoczesnego człowieka w świetle ewolucji, „Analiza i Egzystencja” 19 (2012), s. 235-245. Hermeneutyczne aspekty obrazu świata są też mocno wyeksponowane u analizowanego wcześniej G. Abla.

${ }^{66}$ Uważam, że kiedy filozof chrześcijański uzasadnia swoje tezy, odwołując się do czegoś $\mathrm{w}$ rodzaju bezpośredniej intuicji widzenia czy do innego specyficznego wglądu $\mathrm{w}$ jakieś stany rzeczy (bądź ich oglądu), to tak naprawdę manifestuje swój epistemiczny i ontyczny konserwatyzm, polegający na akceptacji określonego treściowo obrazu świata, w którym pewne rzeczy jawią się jako bezpośrednio dane, a więc oczywiste i niewymagające już żadnych dodatkowych pośrednich uzasadnień - przekonuje P. Gutowski. Przykładem może być np. Maritain, który pisał o spontanicznym przeświadczeniu o istnieniu Boga. Takie podejście dobrze pokazuje artykuł W. Pietkun, Nasze samorzutne przeświadczenie o istnieniu Boga, „Collectanea Theologica” 1956 (27), s. 34-52. Kontynuując dygresję, można powiedzieć, że stwierdzenie, które stany rzeczy są konieczne, a które przygodne, również jest konsekwencją obrania za punkt wyjścia takiego, a nie innego obrazu świata. Autor słusznie twierdzi, że to właśnie akceptacja obrazu świata rozstrzyga o tym, co uznajemy za istniejące, a co za nieistniejące, i w jaki sposób możemy to coś poznać, opisać i wyjaśnić. Jak należy rozumieć tę „manifestację konserwatyzmu”? Wydaje się, że konserwatyzm w tym rozumieniu polega na akceptacji takiego obrazu świata, którego składniki nie podlegają wymianie ze względu na przemiany kulturowe i historyczne. Po prostu akceptujemy pewne tezy niezależnie nie od tego, że np. zaprzeczają im dobrze potwierdzone teorie naukowe. Przykład ten pokazuje zależność stosowanej argumentacji od przyjmowanego w danej tradycji obrazu świata. O sprawach tych interesująco pisze P. Gutowski, Metafizyka procesualna a tomizm egzystencjalny, w: Poznanie bytu czy ustalanie sensów, red. A. Maryniarczyk, M.J. Gondek, Lublin 1999, s. 109-132.

${ }^{67}$ Zob. K. Jodkowski, Milczace funkcje paradygmatu, „Studia Filozoficzne” 1981, nr 1 (182), s. 65. Autor, analizując sytuację w nauce, pisze: „Wyuczone przez studiowanie wzorców postrzeganie świata polega na wyróżnianiu w nim rodzin naturalnych, tj. zbiorów, których elementy bardziej 
oddał Wittgenstein: „uczeń wierzy nauczycielom i podręcznikom" ${ }^{68}$. Również wiara w skuteczność perswazyjną argumentów odgrywa ważną rolę w dyskursie filozoficznym. W argumenty się wierzy lub nie. Nie mają one aż takiej mocy zniewalającej, aby wpływać na osobowe decyzje. Argument może kogoś przekonać lub nie ${ }^{69}$, a przekonanie czy nieprzekonanie jest zawsze uwarunkowane akceptowanym obrazem świata (tłem), który umożliwia lub nie przyjęcie określonego ciągu argumentów. U podstaw wiary w argument znajduje się nie do końca wypowiedziana wiedza tła, czyli obraz świata, wraz z funkcjonującymi w nim heurystykami, których wpływ na nasze myślenie zaczynamy sobie stopniowo uświadamiać pod wpływem krytycznej refleksji i edukacyjnego treningu. Zaakceptowanym tezom przedmiotowym przypisuje się w strukturze obrazu świata różny status epistemologiczny; od tez obdarzonych bezwarunkową oczywistością, których korelatem jest nie tylko subiektywne przeżycie, ale obiektywna rzeczywistość, do takich, które mogą być poddane rewizji za pomocą różnych rodzajów zabiegów interpretacyjnych. Przeważnie to autorytet naszych nauczycieli decyduje o tym, które tezy i przez jaki czas uznajemy za oczywiste. $\mathrm{W}$ tym kontekście ważna jest epistemiczna rola zaufania, na którym stopniowo konstytuuje się podmiotowy akt wiary, co następnie prowadzi do akceptacji określonych tez ${ }^{70}$. Filozofowie chrześcijańscy wierzą, że ich obraz świata jest prawdziwym i adekwatnym obrazem, wiernie odzwierciedlającym obiektywną rzeczywistość. Trzeba wyraźnie zaznaczyć,

przypominają się wzajemnie niż są podobne do elementów innych rodzin naturalnych. Zakres tych rodzin jest nieostry. Warunkiem koniecznym bezpośredniego rozpoznawania elementów rodzin naturalnych (tj. bez posługiwania się wyraźnymi kryteriami) jest istnienie pustych przestrzeni perceptualnych między wyróżnianymi rodzinami. Obraz świata, to perceptualnie nieciągłe kategorie. Gdyby owe puste przestrzenie perceptualne nie istniały, obraz świata byłby konwencjonalny - mogłoby być tak, że za jeden przedmiot uchodziłoby moje ucho i kawałek Księżyca. Różnice między przyjmowanymi zbiorami wzorców stanowią najbardziej o wspólnotowej strukturze nauki. Wszyscy uczeni danej dyscypliny zaczynają od tych samych wzorcowych problemów i instrumentów badawczych. W miarę rozwijania treningu, prawa, a raczej symboliczne generalizacje są ciągle ilustrowane przez coraz to nowe wzorce. Dochodzi do tego, że uczeni z dwu dziedzin danej dyscypliny mogą przyjmować to samo prawo, różniąc się prawie zupełnie znajomością jego zastosowań”. Tamże, s. 61 . Uważam, że przeprowadzona charakterystyka odnosi się również do filozofów, którzy w ramach różnych tradycji badawczych stawiają i rozwiązują określone zadania.

${ }^{68}$ L. Wittgenstein, O pewności, s. 59.

${ }^{69}$ Zob. M. Tokarz, Dlaczego nie przekonują nas przekonywające argumenty, „Filozofia Nauki” 15 (2007), nr 1, s. 5-18.

${ }^{70}$ Epistemiczne aspekty wiary i zaufania objaśnia Stróżewski: „Oto lekarz informuje mnie, że jedynym rozwiązaniem moich dolegliwości jest operacja. Mogę mu wierzyć lub nie wierzyć, jeśli jednak uwierzę, to dlatego, że mam do niego zaufanie. Zaufanie jest więc warunkiem mojej wiary. A opiera się ono na wiedzy, że ów lekarz jest znakomitym specjalistą. I dlatego właśnie mogę mu zaufać. Zaufanie jest tym głębsze, im lepiej znam tego, komu ufam. Najlepiej, gdy jest to znajomość wypróbowana, choćby owym przysłowiowym «zjedzeniem beczki soli». W. Stróżewski, O przeświadczeniach, „Przegląd Filozoficzny - Nowa Seria” R. 21 (2012), nr 2 (82), s. 23. Sprawa ta w odniesieniu do akceptacji obrazów świata wymaga rozwinięcia. 
że w pierwszej kolejności wierzą oni, a dopiero potem starają się to wszystko jakoś racjonalnie uzasadnić, usystematyzować i zakomunikować określonemu audytorium. Sprawa systematyzacji i uzasadnienia otwiera przed nami nowe pole problemów, z ich szczegółowego objaśnienia muszę na tym etapie analiz zrezygnować. Pozostawiając bez dalszego komentarza powyższe stwierdzenia, zaznaczę tylko, że żaden obraz świata nie zniewala nas nigdy w sposób ostateczny. Może tak być, tylko jeśli sami się na to zgodzimy, ale nawet i taka decyzja uwarunkowana jest określonymi motywami, które powstają pod wpływem czynników społecznych i środowiskowych. Generalnie rzecz ujmując, prawda (można dodać żadna prawda) tkwiąca w obrazie świata nigdy nie broni się sama. Dlatego zawsze możliwa jest zmiana obrazu świata na inny, który bardziej odpowiada naszym intelektualnym potrzebom, wrażliwości emocjonalnej, a także preferencjom grupy społecznej, w której przyszło nam żyć. Zmiana ta przybiera w niektórych sytuacjach formę szczególnej konwersji.

Christian Philosophy and the IMAge OF THE WORLD.

Notes FROM THE PERSPECTIVE OF THE SOCIOLOGY OF PHILOSOPHY

\section{S UMMARY}

In this article, I present a proposal to study Christian philosophy understood as a research tradition from the perspective of the sociology of philosophy. For a sociologist of philosophy, Christian philosophy is a specific empirical phenomenon that we can learn by discovering the mechanisms of its functioning. The article focuses on the issue of accepting the image of the world that defines the identity of Christian philosophy. The task of the sociology of philosophy is to discover the mechanisms that influence the context of acceptance of this image of the world. The sociology of philosophy distances itself from assessing the truth or falsehood of the content of theses advocated by individual philosophers. Although each philosophy develops according to the principles of the so-called immanent logic, it is, however, certain social and psychological factors that influence what a given philosopher accepts as obvious and beyond discussion. In the article, I showed that the acceptance of the image of the world is a consequence of upbringing that takes place in a specific social group (e.g. family, school) which shares certain axiological ideas and descriptive beliefs. Thanks to the upbringing, in the future student of philosophy, who always remains a child of his time and culture, the mental and emotional ground is prepared for the acceptance of an already more speculative image of the world, which the adept gets acquainted with during professional university studies (philosophy or theology) under the supervision of recognized by him authorities. The mind, shaped by specific educational processes, is able to 
carry out a personal and holistic act of epistemic faith in a specific picture of the world that is given to it through theories and educational practice. Acceptance and involvement in the image of the world enables the formulation of specific argumentation strategies within it, the task of which is (i) explication, (ii) explanation and (iii) justification of the objective consequences of the image of the world. We adopt argumentative practices through training, we learn them both orally and in writing, of course under the supervision of those who have practically tried these arguments themselves. The student simply believes teachers and textbooks. Up to a certain point, this belief is rational. The image of the world as a whole, consisting of content-descriptive and normative beliefs, is not subject to any final rational justification. The accepted theses are assigned a different epistemological status; from theses endowed with unconditional obviousness, the correlate of which is not only subjective experience, but also objective reality, to those that can be subjected to a more or less creative revision by means of various kinds of interpretative procedures. No picture of the world is ultimately captivating. It is always possible to change the image of the world to a different one that better suits our intellectual needs and emotional sensitivity. This change takes the form of a specific conversion in certain situations.

Keywords: Christian philosophy, sociology of philosophy, philosophy of science, epistemology, meta-science, Thomism, worldview, Polish philosophy

Słowa kluczowe: filozofia chrześcijańska, socjologia filozofii, filozofia nauki, epistemologia, metanauka, tomizm, obraz świata, filozofia polska

\section{BIBLIOGRAFIA}

Abel G., Świat jako znak i interpretacja, tłum. W. Małecki, Warszawa 2014.

Abriszewski K., Budowanie sieci zamiast wiedzy. Krótkie wprowadzenie do ANT-ologii, w: Teoretyczne podstawy socjologii wiedzy, t. 1, red. P. Bytniewski, M. Chałubiński, Lublin 2006, s. 271-287.

Heidegren C.G., Lundberg H., Towards a Sociology of Philosophy, „Acta Sociologica” 53 (2010), s. 3-18.

Dennet D., Dźwignie wyobraźni i inne narzędzia do myślenia, thum. Ł. Kurek, Kraków 2015.

Duchliński P., Kobyliński A., Moń R., Podrez E., Inspiracje chrześcijańskie w etyce, Kraków 2016.

Encyklika Leona XIII, Aeterni Patris, Warszawa, 2003.

Encyklika Fides et ratio Ojca Świętego Jana Pawła II do biskupów Kościoła katolickiego O relacjach między wiarą i rozumem, nr 1. Tekst polski wydany przez Pallottinum, Poznań 1998.

Fellman F., Samorozumienie nowoczesnego czlowieka w świetle ewolucji, „Analiza i Egzystencja” 19 (2012), s. 235-245.

Filozoficzne i naukowo-przyrodnicze elementy obrazu świata, red. A. Latawiec, A. Lemańska, Warszawa 1998.

Gałecki S., O możliwości istnienia filozofii chrześcijańskiej, „Ruch Filozoficzny” 2016, nr 3, s. $117-132$.

Gutowski P., Metafizyka procesualna a tomizm egzystencjalny, w: Poznanie bytu czy ustalanie sensów, red. A. Maryniarczyk, M.J. Gondek, Lublin 1999, s. 109-132. 
Hajduk Z., Restrykcjonizm - ekspansjonizm: Spór o wartości poznawcze i pozapoznawcze w nauce, „Sprawozdanie Towarzystwa Naukowego KUL” 34 (54) 2005, s. 55-73.

Hajduk Z., Wartości epistemiczne: aktualne kontrowersje w aksjologii nauki, w: Wartości dla życia, red. K. Popielski, Lublin 2008, s. 117-133.

Hajduk Z., Wartościowanie i wartości w nauce, „Studia Philosophiae Christianae” 40 (2004), nr 2, s. $13-38$.

Heller M., Naturalizm teologiczny Józefa Życińskiego, w: J. Życiński, Transcendencja i naturalizm, Kraków 2014, s. 9-14.

Heller M., Nauka i teologia - niekoniecznie tylko na jednej planecie, Kraków 2019.

Heller M., Naukowy obraz świata a zadanie teologa, w: Obrazy świata w teologii i naukach przyrodniczych, red. M. Heller, S. Budzik, S. Wszołek, Tarnów 1996, s. 13-28.

Heller M., Przeciw fundacjonizmowi, w: M. Heller, Filozofia i wszechświat, Kraków 2006, s. 82-101.

Heller M., Teologia i wszechświat, Tarnów 2008.

Hesse M., Revolutions and Reconstructions in the Philosophy of Science, Brington 1980.

Hohol M., Brożek B., Homo fundamentalis, https://www.miesiecznik.znak.com.pl/homo-fundamentalis/ [dostęp: 2.05.2021].

Jodkowski K., Milczace funkcje paradygmatu, „Studia Filozoficzne” 1981, nr 1 (182), s. 53-65.

Kmita J., O kulturze symbolicznej, Warszawa 1982.

Kmita J., Z metodologicznych problemów interpretacji humanistycznej, Warszawa 1971.

Kossowska M., Umyst niezmienny... Poznawcze mechanizmy sztywności, Kraków 2005.

Kot D., Historia pewnego rozczarowania. Spór Tischnera z tomistami, https://www.miesiecznik.znak.com.pl/kot-historia-pewnego-rozczarowania-spor-tischnera-z-tomistami/ [dostęp: 28.04.2021].

Koyré A., Galilée et Platon, w: A. Koyré, Études d'histoire de la pensée scientifique, Paris 1973, s. 24-49.

Kraśko N., Instytucjonalizacja socjologii w Polsce 1970-2000, Warszawa 2010.

Longino H., The Social Dimensions of Scientific Knowledge, https://plato.stanford.edu/entries/ scientific-knowledge-social/ [dostęp: 3.05.2021].

Lubański L., Uwagi w sprawie tzw. naukowego obrazu świata, w: Obrazy świata w teologii i naukach przyrodniczych, red. M. Heller, S. Budzik, S. Wszołek, Tarnów 1996, s. 28-42.

Malikowski M., Instytucjonalizacja, dezinstytucjonalizacja a zmiana społeczna, „Ruch Prawniczy, Ekonomiczny i Socjologiczny" LIII (1991), z. 3, s. 133-143.

Niźnik J., Socjologia wiedzy. Zarys historii i problematyki, Warszawa 1989.

Nowak L., Byt i myśl. U podstaw negatywistycznej metafizyki unitarnej, t. 1: Nicość i istnienie, Poznań 1998.

Parsons T., Struktura społeczna a osobowość, tłum. M. Tabin, Warszawa 1969.

Pieter J., O pochodzeniu filozofii, „Przegląd Filozoficzny” 1939, s. 1-64.

Pieter J., Problemy humanisty, Warszawa 2018.

Pieter J., Światopogląd humanisty, Katowice 2019.

Pietkun W., Nasze samorzutne przeświadczenie o istnieniu Boga, „Collectanea Theologica” (1956), nr 27, s. 34-52.

Poczobut R., Czynności i władze poznawcze. Dwa ujęcia. Klasyczne i kognitywistyczne, w: Dydaktyka filozofii. Epistemologia, red. S. Janeczek, A. Starościc, Lublin 2015, s. 243-244.

Przewodnik po polskiej filozofii chrześcijańskiej XX i XXI wieku, red. P.S. Mazur, P. Duchliński, P. Skrzydlewski, Kraków 2020.

Putnam H., Wiele twarzy realizmu i inne eseje, thum. A. Grobler, Warszawa 1998.

Quine W., Dwa dogmaty empiryzmu, w: W. Quine, Z punktu widzenia logiki. Dziewięć esejów logiczno-filozoficznych, thum. B. Stanosz, Warszawa 2000, s. 35-70.

Rokeach M., Umyst zamknięty i otwarty, thum. E. Wojtych, Warszawa 2019.

Sellars W., Philosophy and the Scientific Image of Man, w: W. Sellars, Science, Perception and Reality, Atascadero [USA, California] 1991, s. 1- 41. 
Shils E., The Calling of Sociology and Other Essays on the Pursuit of Learning. Selected Papers of Edward Shils, t. 3, University of Chicago Press, 1980.

Siemianowski A., Spór o aktualna wartość tomizmu, „Więź” 1963, nr. 11-12, s. 30-39.

Słomka M., Antyewolucyjny kreacjonizm we wspótczesnej Polsce i jego wpływ na edukację religijna, ,Roczniki Filozoficzne” t. LXVIII, (2020), nr 4, s. 133-167.

Sojak R., Socjologia wiedzy chce pozostać nieświadoma. Uwagi o statusie poznawczym socjologii wiedzy, „Studia Socjologiczne” 1996, nr 4, s. 25-49.

Sojak R., Wicenty D., Zagubiona rzeczywistość. O społecznym konstruowaniu niewiedzy, Warszawa 2005.

Stachewicz K., O filozofii chrześcijańskiej. Kilka uwag z perspektywy historycznej i futurologicznej, „Logos i Ethos” 2 (35), 2013, s. 219-234.

Stróżewski W., O przeświadczeniach, „Przegląd Filozoficzny - Nowa Seria” R. 21 (2012), nr 2 (82), s. 10-27.

Szahaj A., O tak zwanym mocnym programie socjologii wiedzy szkoły edynburskiej, „Kultura Współczesna" (1995), nr 1-2, s. 53-67.

Szubka T., Wilfrid Sellars and the Two Images of the World, „Ruch Filozoficzny” LXXV (2019), nr 2, s. 131-144.

Swieżawski S., Dzieje europejskiej filozofii klasycznej, Warszawa 2000.

Śleziński K., Filozoficzne implikacje zmieniającego się obrazu rzeczywistości przyrodniczej, „Ruch Filozoficzny” LXXV (2019), nr 3, s. 153-167.

Teoretyczne podstawy socjologii wiedzy, t. 1, red. P. Bytniewski, M. Chałubiński, Lublin 2006,

Tischner J., Myślenie wobec wartości, Kraków 1993.

Tischner J., Schyłek chrześcijaństwa tomistycznego, „Znak” 1970, nr 1, s. 1-20.

Tokarz M., Dlaczego nie przekonuja nas przekonywajace argumenty, „Filozofia Nauki” 15/1 (2007), s. 5-18.

Turek J., Problem wyboru najlepszego wyjaśniania filozoficznego faktów naukowych, „Studia Philosophiae Christianae" 43 (2009), nr 1, s. 179-199.

Tyl M., Zapomniany spór o tomizm, „Folia Philosophica” t. 40 (2018), s. 5-15.

Vitz T., Doxastic Voluntarism, The Internet Encyclopedia of Philosophy, https://iep.utm.edu/home/ about/ [dostęp: 2.05.2021].

Wittgenstein L., O pewności, thum. W. Sady, Warszawa 2014.

Woleński J., Dwa pojęcia nauki: metodologiczne i socjologiczne, „Prace Komisji Historii Nauki” 9 (2009), s. 163-175.

Wójtowicz M., Wspótczesna debata wokół koncepcji woluntaryzmu doksastycznego, „Przegląd Filozoficzny - Nowa Seria" R. 21 (2021), nr 2 (82), s. 411-423.

Zdybicka J.Z., Zieliński I.E., Chrześcijańska filozofia, w: Powszechna encyklopedia filozofii, red. A. Maryniarczyk i in., t. 2, Lublin 2001, s. 163-171.

Ziółkowski M., Wiedza - Jednostka - Społeczeństwo. Zarys koncepcji socjologii wiedzy, Warszawa 1989.

Życiński J., Elementy filozofii nauki, Tarnów 1994.

Życiński J., Racjonalność nauki a socjologiczny redukcjonizm Szkoły Edynburskiej, „Studia Philosophiae Christianae" 26 (1990), nr 1, s. 109-128.

Życiński J., Struktura rewolucji metanaukowej. Studium rozwoju współczesnej nauki, Kraków 2013.

Życiński J., Teizm i filozofia analityczna, t. 1, Kraków 1985.

Życiński J., Transcendencja i naturalizm, Kraków 2014.

Życiński J., W kręgu nauki i wiary, Kalwaria 1989. 